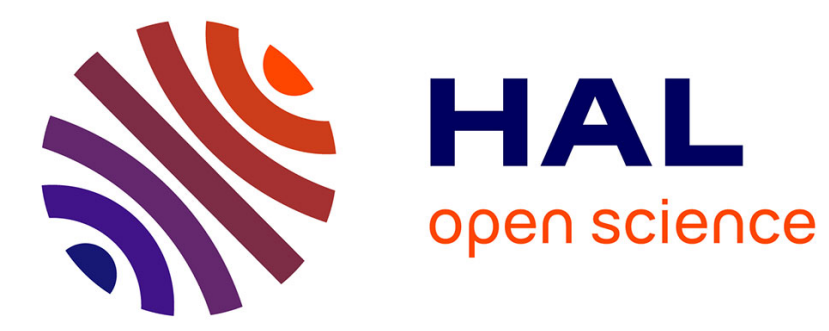

\title{
Glacial/interglacial changes in sediment rain rate in the SW Indian sector of subantarctic waters as recorded by ${ }^{230} \mathbf{T h},{ }^{231} \mathbf{P a}, \mathbf{U}$, and $\delta^{15} \mathbf{N}$
}

Roger Francois, Michael Bacon, Mark Altabet, Laurent Labeyrie

\section{- To cite this version:}

Roger Francois, Michael Bacon, Mark Altabet, Laurent Labeyrie. Glacial/interglacial changes in sediment rain rate in the SW Indian sector of subantarctic waters as recorded by ${ }^{230} \mathrm{Th},{ }^{231} \mathrm{~Pa}$, U, and $\delta^{15} \mathrm{~N}$. Paleoceanography, 1993, 8 (5), pp.611-629. 10.1029/93PA00784 . hal-03584506

\author{
HAL Id: hal-03584506 \\ https://hal.science/hal-03584506
}

Submitted on 22 Feb 2022

HAL is a multi-disciplinary open access archive for the deposit and dissemination of scientific research documents, whether they are published or not. The documents may come from teaching and research institutions in France or abroad, or from public or private research centers.
L'archive ouverte pluridisciplinaire $\mathbf{H A L}$, est destinée au dépôt et à la diffusion de documents scientifiques de niveau recherche, publiés ou non, émanant des établissements d'enseignement et de recherche français ou étrangers, des laboratoires publics ou privés. 
PALEOCEANOGRAPHY, VOL. 8, NO. 5, PAGES 611-629, OCTOBER 1993

\author{
GLACIAL/NTERGLACIAL CHANGES IN SEDIMENT \\ RAIN RATE IN THE SW INDIAN SECTOR OF \\ SUBANTARCTIC WATERS AS RECORDED BY ${ }^{230} \mathrm{Th}$, \\ ${ }^{231} \mathrm{~Pa}, \mathrm{U}$, AND $\delta^{15} \mathrm{~N}$
}

Roger Francois, Michael P. Bacon, and Mark A. Altabet

Department of Marine Chemistry and Geochemistry, Woods Hole Oceanographic Institution, Woods Hole, Massachusetts

Laurent D. Labeyrie

Centre des Faibles Radioactivités, Laboratoire Mixte, Centre National de la Recherche Scientifique et Commissariat à l'Ėnergie Atomique, Gif-sur-Yvette, France

\begin{abstract}
High-resolution records of opal, carbonate, and terrigenous fluxes have been obtained from a highsedimentation rate core (MD84-527: 43'50'S; 51'19'E; 3269 m) by normalization to ${ }^{230} \mathrm{Th}$. This method estimates paleofluxes to the seafloor on a point-by-point basis and distinguishes changes in sediment accumulation due to variations in vertical rain rates from those due to changes in syndepositional sediment redistribution by bottom currents. We also measured sediment $8^{15} \mathrm{~N}$ to evaluate the changes in nitrate utilization in the overlying surface waters associated with paleoflux variations. Our resulte show that opal accumulation rates on the seafloor during the Holocene and stage 3, based on ${ }^{14} \mathrm{C}$ dating, were respectively tenfold and fivefold higher than the vertical rain rates, At this particular location, changes in opal accumulation on the seafloor appear to be mainly controlled by sediment redistribution by bottom currents rather than variations in opal fluxes from the overlying water column Correction for gyndepositional sediment redistribution and the improved time resolution that can be achieved by normalization to ${ }^{230} \mathrm{Th}$ disclose important variations in opal rain rates. We found relatively high but variable opal paleoflux during stage 3, with two maxima centered at 36 and $30 \mathrm{kyr}$ B.P., low opal paleoflux during stage 2 and deglaciation and a pronounced maximum during the early Holocene, We interpret this record as reflecting variations in opal production rates associated with climateinduced latitudinal migration of the southem ocean frontal system. Sediments deposited during periods of high opal paleoflux also have high authigenic $U$ concentrations, suggesting more reducing conditions in the sediment, and
\end{abstract}

Copyright 1993

by the American Geophysical Union.

Paper number 93PA00784. 0883-8305/93/93PA-00784\$10.00 high Pa-231/Th-230 ratios, suggesting increased scavenging from the water column. Sediment $\delta^{15} \mathrm{~N}$ is circa 1.5 per mil higher during isotopic stage 2 and deglaciation. The low opal rain rates recorded during that period appear to have been associated with increased nitrate depletion. This suggests that opal paleofluxes do not simply reflect latitudinal migration of the frontal system but also changes in the structure of the upper water column Increased stratification during isotopic stage 2 and deglaciation could bave been produced by a meltwater lid, leading to lower nitrate supply rates to surface waters.

\section{INTRODUCTION}

In response to arguments that biological production in highlatitude surface waters may be an important control on the steady state level of atmospheric $\mathrm{CO}_{2}$ [Sarmiento and Toggweiller, 1984; Siegenthaler and Wenk, 1984; Knox and McElroy, 1984], attention has focussed on the accumulation history of opal in sediments from the southern ocean. Thus far, efforts have been directed towards estimating opal accumulation rates in cores with established stratigraphy [Mortlock et al., 1991; Charles et al., 1991; Bareille, 1991; Bareille et al., 1991]. An inherent uncertainty in that approach, however, is the inability to distinguish between changes in accumulation resulting from variations in productivity-controlled vertical rain rate and those resulting from variations in syndepositional sediment redistribution by bottom currents. In the southern ocean, this uncertainty may be especially significant because of the presence of relatively strong abyssal currents associated with the Antarctic Circumpolar Current and Antarctic Bottom Water. Synoptic sediment maps clearly indicate the presence of scour zones produced by high bottom water velocities [Heezen and Hollister, 1971; Watkins and Kennett, 1972; Anderson, 1990]. 


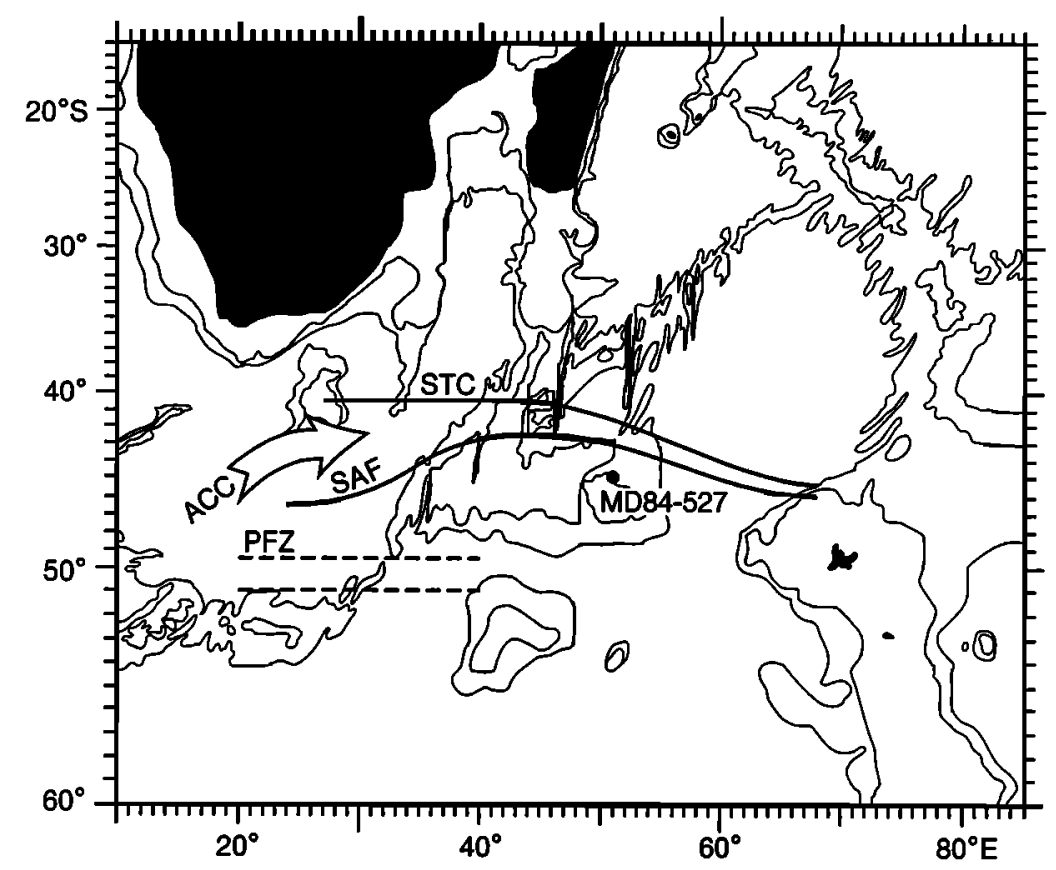

Fig. 1. Core location (MD84-527: 43ㄷㅇ's; $51^{\circ} 19^{\prime} \mathrm{E} ; 3269 \mathrm{~m}$ ) and position of present-day Subtropical Convergence (STC), Sub-Antarctic Front (SAF), and Polar Frontal Zone (PFZ). Also illustrated is the northward deflection of the Antarctic Circumpolar Current (ACC).

Sediment winnowed from these areas is eventually deposited in regions of lower current intensity, where sediment accumulation must be in excess of the vertical particle flux originating from surface water. As opal-rich sediments appear to be particularly susceptible to resuspension, such redistribution may be especially important in the opal-rich zone associated with the Polar Frontal Zone, and it becomes difficult to ascertain whether changes in opal accumulation recorded at any point on the seafloor reflect changes in productivity in the overlying water or simply result from shifts in the position or intensity of bottom currents, leading to changes in the amount of sediment brought to the site by lateral transport.

In a recent study of Holocene sedimentation on the Bermuda Rise drift deposit, Suman and Bacon [1989] addressed this problem. They demonstrated that, by normalizing to excess ${ }^{230} \mathrm{Th}$ activity in the sediment, changes in vertical pelagic rain rates could be reconstructed even from cores collected in areas where sediment accumulation is dominated by lateral transport of sediment by bottom currents. They used the term "sediment focusing" to convey the idea that this redistribution results in the accumulation of sediment in excess of what is produced in the overlying water column. We use a similar approach in a core from the SW Indian sector of the southern ocean (MD84-527; 434․35'S, 51 ${ }^{\circ} 19.1 \mathrm{E} ; 3269 \mathrm{~m}$; Figure 1). The isotopic and micropaleontological records of this core have been extensively studied [Labeyrie et al., 1986; Labracherie et al., 1989; Pichon et al., 1992], and detailed ${ }^{14} \mathrm{C}$ A.M.S. dating shows large variations in sediment accumulation rates apparently associated with Quaternary climatic cycles [Bard et al., 1989; Labracherie et al., 1989] (Figure 2). This core thus provides an opportunity to further

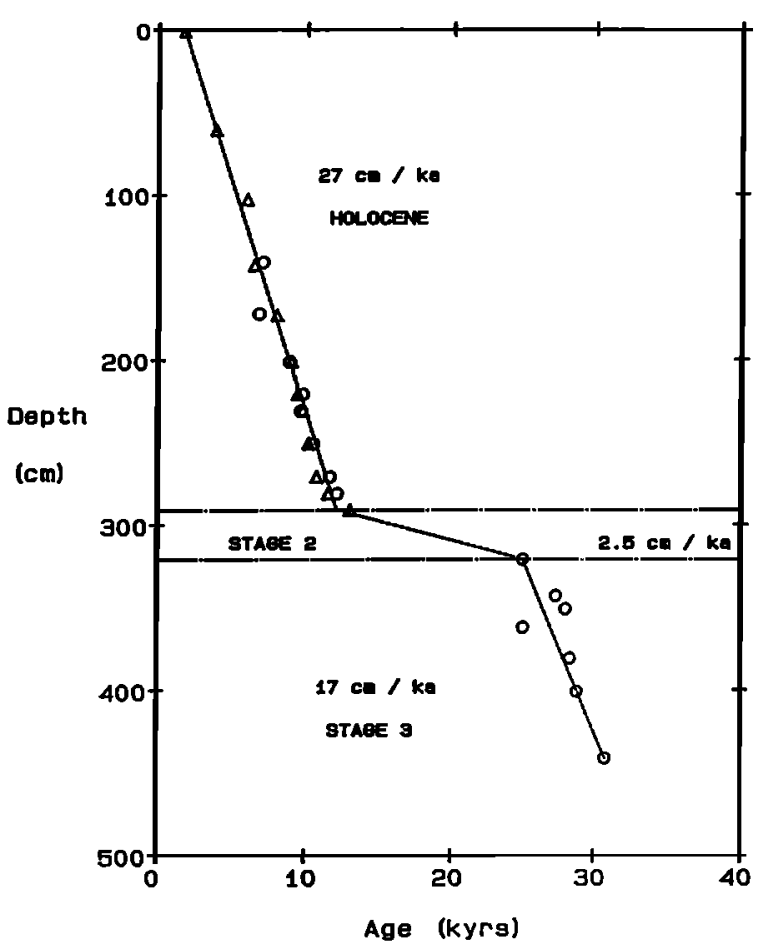

Fig. 2. Accelerator mass spectrometer ${ }^{14} \mathrm{C}$ dates on planktonic foraminifera (triangles, G. bull.; circles, $N$. pachyd.). Data from Labracherie et al. [1989]. 
test the potential of excess ${ }^{230} \mathrm{Th}$ normalization as a means of retrieving paleoflux (or pelagic rain rate) information from the sedimentary record, to estimate the impact of sediment redistribution (or sediment focusing) on opal accumulation rates in this region, and to study variations in opal and carbonate rain rate in subantarctic waters during the last 40,000 years.

In addition to excess ${ }^{230} \mathrm{Th}$, we also measured excess ${ }^{231} \mathrm{~Pa}$, authigenic uranium, and bulk sediment $\delta^{15} \mathrm{~N}$. Protactinium231 is preferentially scavenged (relative to ${ }^{230} \mathrm{Th}$ ) in areas of higher particle flux [Anderson et al., 1983; Yang et al., 1986; Bacon, 1988; Anderson et al., 1990; Lao et al., 1993], so that excess ${ }^{231} \mathrm{~Pa} /$ excess ${ }^{230} \mathrm{Th}$ ratios in sediments can be used to identify areas of the seafloor subjected to higher particle rain rates. Authigenic $U$ concentrations reflect reducing conditions in sediments [Cochran and Krishnaswami, 1980; Barnes and Cochran, 1990; Klinkhammer and Palmer, 1991] which can be linked to higher primary production in the overlying water column. We will show that the sediment profiles of these other constituents are consistent with the conclusions derived from ${ }^{230} \mathrm{Th}$ normalization. Finally, sediment $\delta^{15} \mathrm{~N}$ was measured to evaluate changes in nitrate utilization in surface waters [Calvert et al., 1992; Francois et al., 1992; M. A. Altabet and R. Francois, Sedimentary nitrogen isotopic ratio records surface ocean nitrate utilization, submitted to Global Biogeochemical Cycles, 1993 (hereinafter referred to as Altabet and Francois, submitted manuscript, 1993)] associated with the recorded changes in paleoflux.

\section{ANALYTICAL METHODS}

$U, T h$ and $P a$ isotopes: $\mathrm{U}, \mathrm{Th}$, and $\mathrm{Pa}$ isotopes were measured by $\alpha$ spectrometry after separation on anion exchange resins (AG1-X8, 100-200 mesh) and electrodeposition on silver disks. The procedure of Anderson

TABLE 1. The ${ }^{230} \mathrm{Th},{ }^{231} \mathrm{~Pa},{ }^{234} \mathrm{U}$, and ${ }^{238 \mathrm{U}}$ Activities in Core MD84-527

\begin{tabular}{|c|c|c|c|c|c|c|}
\hline $\begin{array}{c}\text { Depth, } \\
\text { cm }\end{array}$ & $\begin{array}{c}\text { Time*, } \\
\text { ka }\end{array}$ & $\begin{array}{l}\text { 230Th, } \\
\mathrm{dpm} / \mathrm{g}\end{array}$ & $\begin{array}{l}231 \mathrm{~Pa}, \\
\mathrm{dpm} / \mathrm{g}\end{array}$ & $\begin{array}{l}{ }^{234} \mathrm{U} \\
\mathrm{dpm} / \mathrm{g}\end{array}$ & $\begin{array}{c}238 \mathrm{U}, \\
\mathrm{dpm} / \mathrm{g}\end{array}$ & ${ }^{234} \mathrm{U} / 238 \mathrm{U}$ \\
\hline 10 & 2.14 & $9.61 \pm .45$ & & $2.22 \pm .14$ & $2.06 \pm .12$ & $1.08 \pm .07$ \\
\hline 30 & 2.93 & $9.13 \pm .24$ & $0.97 \pm .03$ & $2.45 \pm .18$ & $2.23 \pm .13$ & $1.10 \pm .07$ \\
\hline 78 & 4.66 & $10.63 \pm .27$ & $1.16 \pm .04$ & $2.07 \pm .13$ & $1.83 \pm .11$ & $1.13 \pm .08$ \\
\hline 98 & 5.33 & $9.27 \pm .30$ & $0.84 \pm .06$ & $2.32 \pm .10$ & $2.19 \pm .09$ & $1.06 \pm .05$ \\
\hline 134 & 6.49 & $9.46 \pm .26$ & & $2.71 \pm .14$ & $2.46 \pm .12$ & $1.10 \pm .07$ \\
\hline 158 & 7.31 & $5.67 \pm .18$ & $0.88 \pm .07$ & $2.75 \pm .10$ & $2.39 \pm .08$ & $1.15 \pm .04$ \\
\hline 188 & 8.49 & $5.34 \pm .19$ & $0.75 \pm .06$ & $3.77 \pm .20$ & $3.28 \pm .18$ & $1.15 \pm .06$ \\
\hline 198 & 8.88 & $5.93 \pm .19$ & $0.83 \pm .05$ & $4.28 \pm .16$ & $3.66 \pm .16$ & $1.17 \pm .05$ \\
\hline 218 & 9.48 & $5.57 \pm .18$ & $0.72 \pm .06$ & $3.47 \pm .19$ & $2.92 \pm .17$ & $1.19 \pm .07$ \\
\hline 228 & 9.78 & $5.60 \pm .11$ & $0.87 \pm .06$ & $3.71 \pm .32$ & $3.23 \pm .26$ & $1.15 \pm .11$ \\
\hline 238 & 10.10 & $6.20 \pm .11$ & $0.53 \pm .02$ & $1.85 \pm .16$ & $1.47 \pm .12$ & $1.26 \pm .14$ \\
\hline 246 & 10.30 & $7.58 \pm .25$ & $0.68 \pm .05$ & $1.50 \pm .11$ & $1.47 \pm .10$ & $1.02 \pm .09$ \\
\hline 256 & 10.80 & $8.60 \pm .32$ & & $1.66 \pm .07$ & $1.51 \pm .06$ & $1.10 \pm .06$ \\
\hline 268 & 11.43 & $7.55 \pm .22$ & $0.76 \pm .07$ & $1.34 \pm .06$ & $1.17 \pm .04$ & $1.15 \pm .06$ \\
\hline 289 & 12.70 & $9.89 \pm .42$ & & $1.35 \pm .09$ & $1.30 \pm .07$ & $1.04 \pm .08$ \\
\hline 298 & 15.73 & $8.66 \pm .36$ & $0.71 \pm .07$ & $1.17 \pm .05$ & $1.10 \pm .04$ & $1.06 \pm .06$ \\
\hline 308 & 19.63 & $8.19 \pm .47$ & $0.56 \pm .06$ & $1.12 \pm .11$ & $0.92 \pm .10$ & $1.22 \pm .19$ \\
\hline 318 & 23.50 & $6.52 \pm .31$ & $0.53 \pm .04$ & $1.26 \pm .14$ & $1.22 \pm .12$ & $1.03 \pm .14$ \\
\hline 338 & 26.50 & $5.27 \pm .19$ & $0.48 \pm .05$ & $5.31 \pm .25$ & $4.74 \pm .22$ & $1.12 \pm .05$ \\
\hline 348 & 27.10 & $6.03 \pm .20$ & $0.49 \pm .04$ & $7.01 \pm .30$ & $6.32 \pm .27$ & $1.11 \pm .04$ \\
\hline 386 & 28.80 & $4.31 \pm .13$ & $0.39 \pm .03$ & $2.12 \pm .12$ & $1.93 \pm .11$ & $1.10 \pm .07$ \\
\hline 406 & 30.00 & $4.11 \pm .12$ & $0.40 \pm .03$ & $2.07 \pm .20$ & $1.95 \pm .17$ & $1.06 \pm .11$ \\
\hline 428 & 31.30 & $5.33 \pm .10$ & & $2.38 \pm .12$ & $2.29 \pm .12$ & $1.04 \pm .06$ \\
\hline 448 & 32.50 & $5.02 \pm .23$ & $0.34 \pm .02$ & $1.81 \pm .10$ & $1.64 \pm .08$ & $1.10 \pm .07$ \\
\hline 468 & 33.60 & $5.27 \pm .20$ & & $1.50 \pm .10$ & $1.53 \pm .08$ & $0.98 \pm .07$ \\
\hline 485 & 34.60 & $4.71 \pm .17$ & & $1.25 \pm .09$ & $1.21 \pm .08$ & $1.03 \pm .10$ \\
\hline 508 & 36.00 & $4.21 \pm .19$ & $0.35 \pm .03$ & $1.79 \pm .14$ & $1.70 \pm .13$ & $1.05 \pm .09$ \\
\hline 516 & 36.47 & $4.48 \pm .14$ & $0.35 \pm .04$ & $1.88 \pm .07$ & $1.71 \pm .07$ & $1.10 \pm .07$ \\
\hline 528 & 37.20 & $5.87 \pm .22$ & $0.49 \pm .04$ & $2.40 \pm .15$ & $2.14 \pm .13$ & $1.12 \pm .08$ \\
\hline 548 & 38.40 & $4.64 \pm .08$ & $0.30 \pm .04$ & $1.58 \pm .11$ & $1.61 \pm .10$ & $0.98 \pm .08$ \\
\hline
\end{tabular}

* Time scale is based on accelerator mass spectrometry ${ }^{14} \mathrm{C}$ dates [Labracherie et al., 1989, Figure 2]. 
and Fleer [1982] was followed for U and Th. Protactinium231 was analyzed following the procedure described by Fleer and Bacon [1991]. Briefly, ${ }^{231} \mathrm{~Pa}$ was separated from Th isotopes by adsorption on $\mathrm{AGl}-\mathrm{X} 8$ from $9 \mathrm{~N} \mathrm{HCl}$ and from $\mathrm{U}$ isotopes by elution with $12 \mathrm{~N} \mathrm{HCl}$ containing $0.13 \mathrm{~N} \mathrm{HF}$. In the presence of HF, polypropylene columns (chromaflex, Kontes) were used. After elution, the $\mathrm{Pa}$ fractions were evaporated and laken up in $8 \mathrm{~N} \mathrm{HNO}_{3}$. Pa was then readsorbed on $A G 1-X 8$ from $8 \mathrm{~N} \mathrm{HNO}_{3}$, washed with $9 \mathrm{~N} \mathrm{HCl}$ and eluted with $12 \mathrm{~N} \mathrm{HCl} / 0.13 \mathrm{~N} \mathrm{HF}$. The recovered $\mathrm{Pa}$ solutions were then evaporated to a small drop of concentrated $\mathrm{HNO}_{3}$ and taken up in $0.01 \mathrm{M} \mathrm{HNO}_{3}$ and $2 \mathrm{M}$ $\mathrm{NH}_{4} \mathrm{Cl}$ before electroplating. Protactinium-233 was used to monitor chemical yields. Counting efficiencies were estimated by adding known aliquots of ${ }^{241} \mathrm{Am}$ to the $\mathrm{Pa}$ solutions prior to electroplating to serve as an intemal standard. Precisions $(1 \sigma)$ are reported in Table 1.

Calcium carbonate: $\mathrm{CaCO}_{3}$ was measured by a gasometric method [Jones and Kaiteris, 1983]. Precision ranged from 2 to $5 \%$, depending on $\mathrm{CaCO}_{3}$ content.

Opal: Opal was measured by dissolution into $2 \mathrm{M} \mathrm{Na}_{2} \mathrm{CO}_{3}$ at $85^{\circ} \mathrm{C}$ for 5 hours, followed by colorimetric determination [Mortlock and Froelich, 1989]. Duplicate analyses on different samples agreed within 0.2 to $8.7 \%$, with an average $3 \%$ reproducibility. Opal concentrations were obtained by multiplying extracted Si concentrations by 2.4 to account for the average water content of diatomaceous silica [Mortlock and Froelich, 1989].

Terrigenous materials: Detrital aluminosilicates were assumed to make up the remainder (noncarbonate; nonopal) of the sediment.

Sediment $\delta^{15} N$ : Bulk sediment $\delta^{15} \mathrm{~N}$ analyses were made on dried and homogenized sediment samples using the conventional Dumas combustion procedure [Minagawa et al., 1985]. Isotopic analyses were made using a Finnigan MAT 251. Precision, based on reproducibility of a peptone standard, was \pm 0.15 per mil.

Nitrogen: Sediment samples were precisely weighed prior to combustion for nitrogen isotopic analysis. $\mathrm{N}$ was estimated from the ion source intensity on the mass spectrometer. The precision obtained on replicate peptone analyses was $1.6 \%(1 \sigma)$.

\section{PALEOFLUX RECONSTRUCTION BY NORMALIZATION TO EXCESS ${ }^{230} \mathrm{Th}$}

Thorium-230 normalized flux calculations are based on the assumption that the flux of ${ }^{230} \mathrm{Th}$ to the seafloor is constant and equal to the rate of production from the decay of ${ }^{234} \mathrm{U}$ in the overlying water column [Bacon, 1984; Suman and Bacon, 1989; Francois et al., 1990]. Excess ${ }^{230}$ Th activity in settling particulates is then inversely related to total mass flux, and excess ${ }^{230} \mathrm{Th}$ activities (decay corrected) in sediment can be used as a reference against which the flux of other sedimentary components can be estimated:

$$
F_{i}=\frac{\beta \cdot z \cdot f_{i}}{\left[{ }^{230} T h\right]_{0}}
$$

where

$\mathrm{F}_{i} \quad$ normalized flux (rain rate) of sedimentary component $i$; $\beta \quad$ constant production rate of ${ }^{230} \mathrm{Th}$ in the water column $\left(2.63 \times 10^{-5} \mathrm{dpm} \mathrm{cm}^{-3} \mathrm{kyr}^{-1}\right)$;

z water depth;

$\mathrm{f}_{i} \quad$ weight fraction of component $i$ in the sediment;

$[230 \mathrm{Th}]_{0}$ activity of excess ${ }^{230} \mathrm{Th}$ (i.e., the fraction of ${ }^{230} \mathrm{Th}$ not supported by ${ }^{234} \mathrm{U}$ present in mineral lattices) decay corrected to time of deposition using an independent time scale based on ${ }^{14} \mathrm{C}$ or $\delta^{18} \mathrm{O}$ stratigraphy.

By normalizing to $\left[{ }^{230} \mathrm{Th}\right]_{0}$, each point becomes a measure of flux, and the extent to which variations in flux can be resolved is, in principle, limited only by bioturbation.

The validity of the underlying assumption has been verified by ${ }^{230}$ Th flux estimates obtained from sediment traps deployed for at least 1-year periods in different oceanic regions ranging from the Sargasso Sea to the Antarctic Ocean [Francois et al., 1990; E.-F. Yu, unpublished data, 1993]. The data indicate that while total mass flux collected by the traps varies 15 -fold between low- and high-productivity regions, the accompanying flux of ${ }^{230} \mathrm{Th}$ varies only from a deficit (compared to ${ }^{230} \mathrm{Th}$ production rate) of circa $40 \%$ in oligotrophic regions to an excess of circa $50 \%$ in high flux areas. Larger deficits ( $>50 \%$ ) have been observed in traps deployed in oligotrophic regions close to ocean margins, at relatively shallow depths (1000 m or less [Lao et al., 1993; E.-F. Yu, unpublished data, 1993]), suggesting that boundary scavenging might be more pronounced in the upper water column, where circulation is more intense. As most deep-sea sediments are deposited at much greater depths, this effect should have a relatively minor influence on the application of the constant ${ }^{230}$ Th flux model, as reflected by the sediment traps deployed at greater depths. Therefore, although paleoflux reconstructions based on this method tend to underestimate high rain rates and overestimate low ones, we believe that, in most instances, the accuracy of the reconstructed fluxes should be within $40 \%$, while small changes in rain rate can be resolved within the precision of the ex. ${ }^{230} \mathrm{Th}_{0}$ analysis (i.e., better than $5 \%$ ).

\section{NITRATE UTILIZATION RECONSTRUCTION FROM SEDIMENT $\delta^{15} \mathrm{~N}$}

The underlying principle of this approach is detailed in Altabet and Francois (submitted manuscript, 1993) and Francois et al. [1992]. Phytoplankton discriminate against ${ }^{15} \mathrm{~N}$ during nitrate uptake [Wada and Hattori, 1978; Montoya, 1990]. As a result, the $\delta^{15} \mathrm{~N}$ of sinking organic matter increases as nitrate becomes more depleted in surface waters [e.g., Altabet et al., 1991; Nakatsuka et al., 1992], and the $\delta^{15} \mathrm{~N}$ of suspended particulate organic matter (POM) has been found to decrease markedly across the Subtropical Convergence, from circa +7 per mil in the oligotrophic water just north of the convergence to circa -2 per mil in the cold nitrate-rich water of the subpolar and polar regions (Altabet and Francois, submitted manuscript, 1993). Analysis of core tops revealed that the $\delta^{15} \mathrm{~N}$ of total nitrogen in the underlying sediment reflects the signal produced in surface waters. Sediment $\delta^{15} \mathrm{~N}$ was low (circa +5 per mil) in the polar region and increased gradually across the subpolar region to a maximum (circa +11 per mil) just north of the Subtropical 
Convergence. Early diagenesis appears to increase $\delta^{15} \mathrm{~N}$ at the sediment-water interface by 5 to 7 per mil, but the fact that we can nonetheless recognize the expected pattern of $\delta^{15} \mathrm{~N}$ distribution in core tops indicates that diagenetic overprinting does not obliterate the surface signal, but instead offsets it by a more or less constant value. These observations lead to the suggestion that sediment $\delta^{15} \mathrm{~N}$ could be used as an indicator of past changes in the degree of nitrate utilization in the overlying water column, as higher nutrient utilization would translate into higher $\delta^{15} \mathrm{~N}$ in sediment [Altabet and Francois, submitted manuscript, 1993; Francois et al., 1992].

\section{CORE LOCATION}

Core MD84-527 was collected on the N.E. slope of Crozet Plateau (Figure 1), a location underlying the present-day transition zone between warm, saline subtropical surface waters to the north of the Subtropical Convergence $\left(41^{\circ} \mathrm{S}\right.$ $42^{\circ} \mathrm{S}$ ) and cold, less saline, antarctic surface waters to the south of the Polar Frontal Zone $\left(43^{\circ} \mathrm{S}-49^{\circ} \mathrm{S}\right)$. In this sector, the bulk of the geostrophic flow associated with the eastward flowing Antarctic Circumpolar Current (ACC) is diverted to the north of the Crozet Plateau [Gamberoni et al., 1982; Park et al., 1991]. This topographic steering of the bulk of the ACC results in the merging of the Subtropical Convergence and the Subantarctic Front, steep temperature, salinity, and nutrient concentration gradients in surface waters and relatively strong geostrophic currents between $40^{\circ} \mathrm{S}$ and $43^{\circ} \mathrm{S}$.

\section{GLACIAL/INTERGLACIAL CHANGES IN ACCUMULATION RATE}

Core MD84-527 has been extensively dated by accelerator mass spectrometry ${ }^{14} \mathrm{C}$ measured on monospecific planktonic foraminifera samples [Bard et al., 1989; Labracherie et al., 1990]; (Figure 2). The data indicate high accumulation rates during isotopic stage 3 (circa $17 \mathrm{~cm} \mathrm{kyr}^{-1}$ ) and the Holocene (circa $27 \mathrm{~cm} \mathrm{kyr}^{-1}$ ) and a dramatic drop in accumulation rate during isotopic stage 2 (circa $2.5 \mathrm{~cm} \mathrm{kyr}^{-1}$ ). Because of the near absence of foraminifera, there are no ${ }^{14} \mathrm{C}$ dates for the LGM section. The lack of visual or lithological evidence for unconformities suggests a slow but continuous sedimentation over this $30-\mathrm{cm}$ core section, uninterrupted by hiatuses. It seems unlikely that such large and abrupt changes in sedimentation rate would reflect changes only in upper water column processes. Instead, as we will show later, periods of high accumulation represent periods of intensified lateral transport of sediment to the core location, which was chosen to be within a topographic setting promoting sediment accumulation.

\section{RESULTS}

\section{Uranium}

Uranium 238 concentrations (Table 1, Figure 3a) are remarkably high considering the relatively low clay content of the sediment. Because ${ }^{238} \mathrm{U} /{ }^{232} \mathrm{Th}$ activity ratios for most
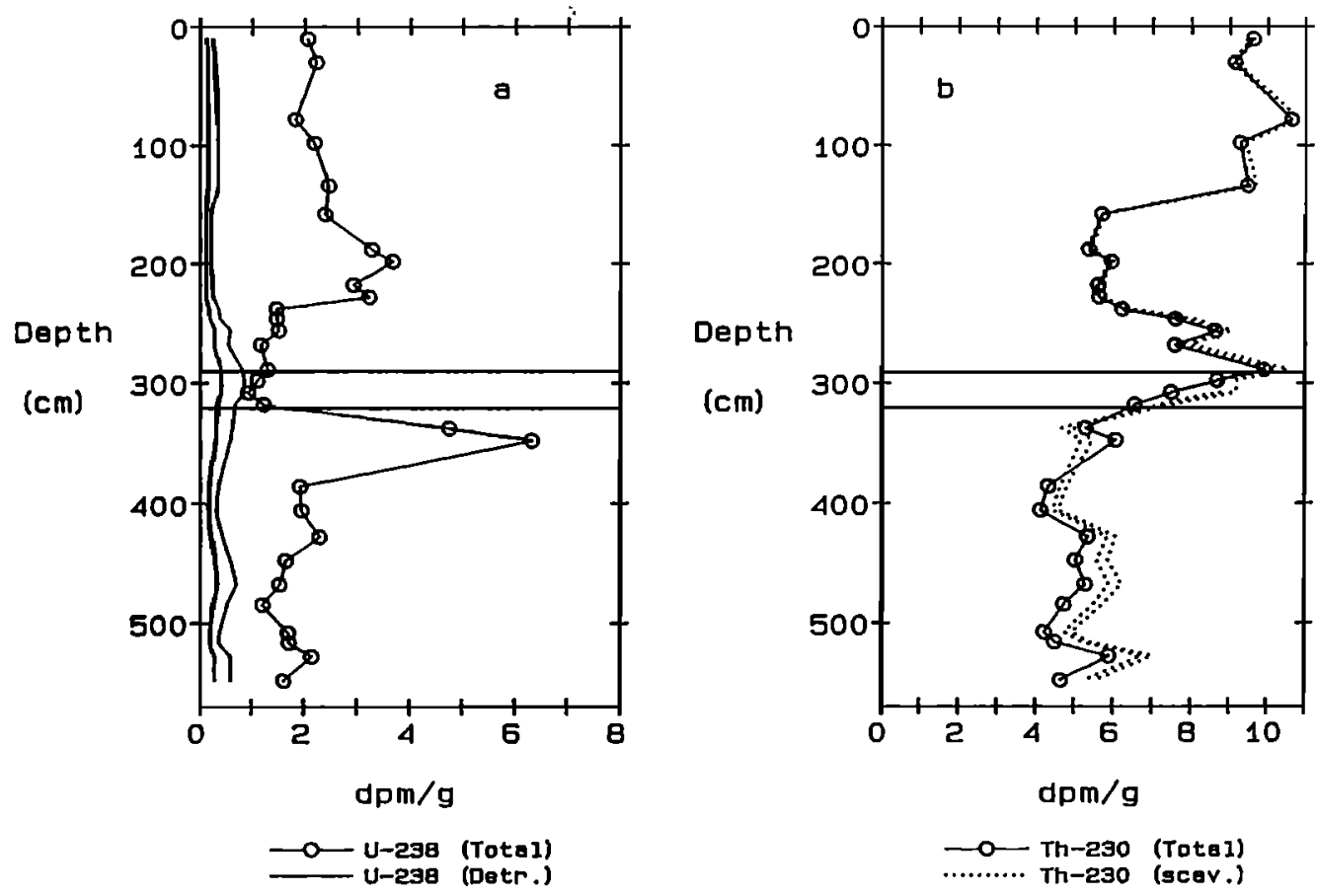

Fig. 3. (a) Uranium-238 activity profile (o) and ${ }^{238} \mathrm{U}$ contribution from the lithogenous sediment component estimated from ${ }^{232} \mathrm{Th}$ activities (the two solid lines represent the range of detrital ${ }^{238} \mathrm{U}$ estimates, assuming ${ }^{238} \mathrm{U} /{ }^{232} \mathrm{Th}$ activity ratio in the sediment detrital phase to be 0.5 and 1). (b) Measured ${ }^{230} \mathrm{Th}$ activity profile (o) and estimated activities of ${ }^{230}$ Th scavenged by settling particulates (decay and ingrowth corrected; dotted lines). The two horizontal lines delineate the core section corresponding to isotopic stage 2. 
TABLE 2. Evaluation of Detrital and Authigenic 238U Activities in Core MD84-527

\begin{tabular}{|c|c|c|c|c|c|}
\hline $\begin{array}{l}\text { Depth, } \\
\text { cm }\end{array}$ & $\begin{array}{c}\text { Time, } \\
\text { ka }\end{array}$ & $\begin{array}{l}\text { 232Th, } \\
\mathrm{dpm} / \mathrm{g}\end{array}$ & $\begin{array}{l}238 \mathrm{U} \\
\mathrm{dpm} / \mathrm{g}\end{array}$ & $\begin{array}{c}\text { Detrital }{ }^{238} \mathrm{U}, \\
\mathrm{dpm} / \mathrm{g}\end{array}$ & $\begin{array}{l}\text { Authigenic }{ }^{238} \mathrm{U}, \\
\mathrm{dpm} / \mathrm{g}\end{array}$ \\
\hline 10 & 2.14 & $0.22 \pm 0.04$ & $2.06 \pm 0.12$ & $0.11-0.22$ & $1.84-1.95$ \\
\hline 30 & 2.93 & $0.29 \pm 0.02$ & $2.23 \pm 0.13$ & $0.15-0.29$ & $1.94-2.08$ \\
\hline 78 & 4.66 & $0.35 \pm 0.02$ & $1.83 \pm 0.11$ & $0.18-0.35$ & $1.48-1.66$ \\
\hline 98 & 5.33 & $0.36 \pm 0.04$ & $2.19 \pm 0.09$ & $0.18-0.36$ & $1.83-2.01$ \\
\hline 134 & 6.49 & $0.36 \pm 0.03$ & $2.46 \pm 0.12$ & $0.18-0.36$ & $2.10-2.28$ \\
\hline 158 & 7.31 & $0.22 \pm 0.02$ & $2.39 \pm 0.08$ & $0.11-0.22$ & $2.17-2.28$ \\
\hline 188 & 8.49 & $0.21 \pm 0.03$ & $3.28 \pm 0.18$ & $0.11-0.21$ & $3.07-3.17$ \\
\hline 198 & 8.88 & $0.21 \pm 0.02$ & $3.66 \pm 0.16$ & $0.11-0.21$ & $3.45-3.55$ \\
\hline 218 & 9.48 & $0.26 \pm 0.03$ & $2.92 \pm 0.17$ & $0.13-0.26$ & $2.66-2.79$ \\
\hline 228 & 9.78 & $0.27 \pm 0.02$ & $3.23 \pm 0.26$ & $0.14-0.27$ & $2.96-3.09$ \\
\hline 238 & 10.10 & $0.36 \pm 0.02$ & $1.47 \pm 0.12$ & $0.18-0.36$ & $1.11-1.29$ \\
\hline 246 & 10.30 & $0.39 \pm 0.04$ & $1.47 \pm 0.10$ & $0.20-0.39$ & $1.08-1.28$ \\
\hline 256 & 10.80 & $0.58 \pm 0.04$ & $1.51 \pm 0.06$ & $0.29-0.58$ & $0.93-1.22$ \\
\hline 268 & 11.43 & $0.55 \pm 0.04$ & $1.17 \pm 0.04$ & $0.28-0.55$ & $0.62-0.89$ \\
\hline 289 & 12.70 & $0.81 \pm 0.07$ & $1.30 \pm 0.07$ & $0.41-0.82$ & $0.49-0.89$ \\
\hline 298 & 15.73 & $0.86 \pm 0.06$ & $1.10 \pm 0.04$ & $0.43-0.86$ & $0.24-0.67$ \\
\hline 308 & 19.63 & $0.89 \pm 0.04$ & $0.92 \pm 0.10$ & $0.45-0.89$ & $0.03-0.47$ \\
\hline 318 & 23.50 & $0.67 \pm 0.07$ & $1.22 \pm 0.12$ & $0.34-0.67$ & $0.55-0.89$ \\
\hline 338 & 26.50 & $0.62 \pm 0.05$ & $4.74 \pm 0.22$ & $0.31-0.62$ & $4.12-4.43$ \\
\hline 348 & 27.10 & $0.59 \pm 0.05$ & $6.32 \pm 0.27$ & $0.30-0.59$ & $5.73-6.02$ \\
\hline 386 & 28.80 & $0.37 \pm 0.03$ & $1.93 \pm 0.11$ & $0.19-0.37$ & $1.56-1.74$ \\
\hline 406 & 30.00 & $0.31 \pm 0.02$ & $1.95 \pm 0.17$ & $0.16-0.31$ & $1.64-1.80$ \\
\hline 428 & 31.30 & $0.44 \pm 0.02$ & $2.29 \pm 0.12$ & $0.22-0.44$ & $1.85-2.07$ \\
\hline 448 & 32.50 & $0.60 \pm 0.07$ & $1.64 \pm 0.08$ & $0.30-0.60$ & $1.05-1.35$ \\
\hline 468 & 33.60 & $0.72 \pm 0.05$ & $1.53 \pm 0.08$ & $0.36-0.72$ & $0.81-1.17$ \\
\hline 485 & 34.60 & $0.53 \pm 0.04$ & $1.21 \pm 0.08$ & $0.27-0.53$ & $0.68-0.95$ \\
\hline 508 & 36.00 & $0.39 \pm 0.04$ & $1.70 \pm 0.13$ & $0.20-0.39$ & $1.31-1.51$ \\
\hline 516 & 36.47 & $0.36 \pm 0.03$ & $1.71 \pm 0.07$ & $0.18-0.36$ & $1.35-1.53$ \\
\hline 528 & 37.20 & $0.58 \pm 0.05$ & $2.14 \pm 0.13$ & $0.29-0.58$ & $1.56-1.85$ \\
\hline 548 & 38.40 & $0.61 \pm 0.02$ & $1.61 \pm 0.10$ & $0.31-0.61$ & $1.00-1.31$ \\
\hline
\end{tabular}

Detrital $238 \mathrm{U}$ activities were estimated by assuming $238 \mathrm{U} / 232 \mathrm{Th}$ activity ratio between 0.5 and 1 . Authigenic $238 \mathrm{U}$ activities were estimated by difference.

major minerals and pelagic marine sediments vary within a narrow range, detrital ${ }^{238} \mathrm{U}$ can be estimated from ${ }^{232} \mathrm{Th}$ activities [Anderson, 1982; Anderson et al., 1989]. An envelope of detrital ${ }^{238} \mathrm{U}$ values was thus estimated, assuming ${ }^{238} \mathrm{U} /{ }^{232} \mathrm{Th}$ activity ratio of the sediment detrital phase in the range of 0.5 to 1 (Table 2, Figure 3a), and authigenic ${ }^{238} \mathrm{U}$ activities were estimated by difference (Table 2 ). Clearly, a large fraction of the uranium found in this core cannot be detrital, but instead must have been added to the sediment as a result of reducing conditions either in the sediment [Cochran and Krishnaswami, 1980; Barnes and Cochran, 1990; Klinkhammer and Palmer, 1991] or in microenvironments within settling particules [Anderson, 1982]. The relatively high ${ }^{234} \mathrm{U} /{ }^{238} \mathrm{U}$ ratios measured in this core (Table 1; average: $1.10 \pm 0.07$ ), similar to that of seawater, are also consistent with this explanation.

\section{Thorium 230}

Because of the addition of relatively large amounts of authigenic $\mathrm{U}$ from seawater into the sediment after deposition, calculation of excess $\left[{ }^{230} \mathrm{Th}\right]_{0}$ (i.e., the amount of ${ }^{230} \mathrm{Th}$ derived by scavenging from seawater, decay corrected to the time of deposition) requires corrections not only for detrital ${ }^{230} \mathrm{Th}$ and decay since the time of deposition but also corrections for ingrowth of ${ }^{230} \mathrm{Th}$ from authigenic ${ }^{234} \mathrm{U}$. If we assume that authigenic $U$ was added at the time of sediment deposition, these corrections can be estimated from the following equation:

$A_{3}{ }^{0}=A_{3} e^{\lambda 3 t}-A_{1}{ }^{0}\left(e^{\lambda 3 s-1}\right)+\left(A_{1}^{0}-A_{2}^{0}\right) \frac{\lambda 3}{\lambda 3-\lambda 2}\left(e^{(\lambda 3-\lambda 2) \cdot t}-1\right)$

where $A_{3}{ }^{\circ}$ is the decay- and ingrowth-corrected ${ }^{230} \mathrm{Th}$ activity 
TABLE 3. Decay- and Ingrowth-Corrected Excess 230Th and 231Pa

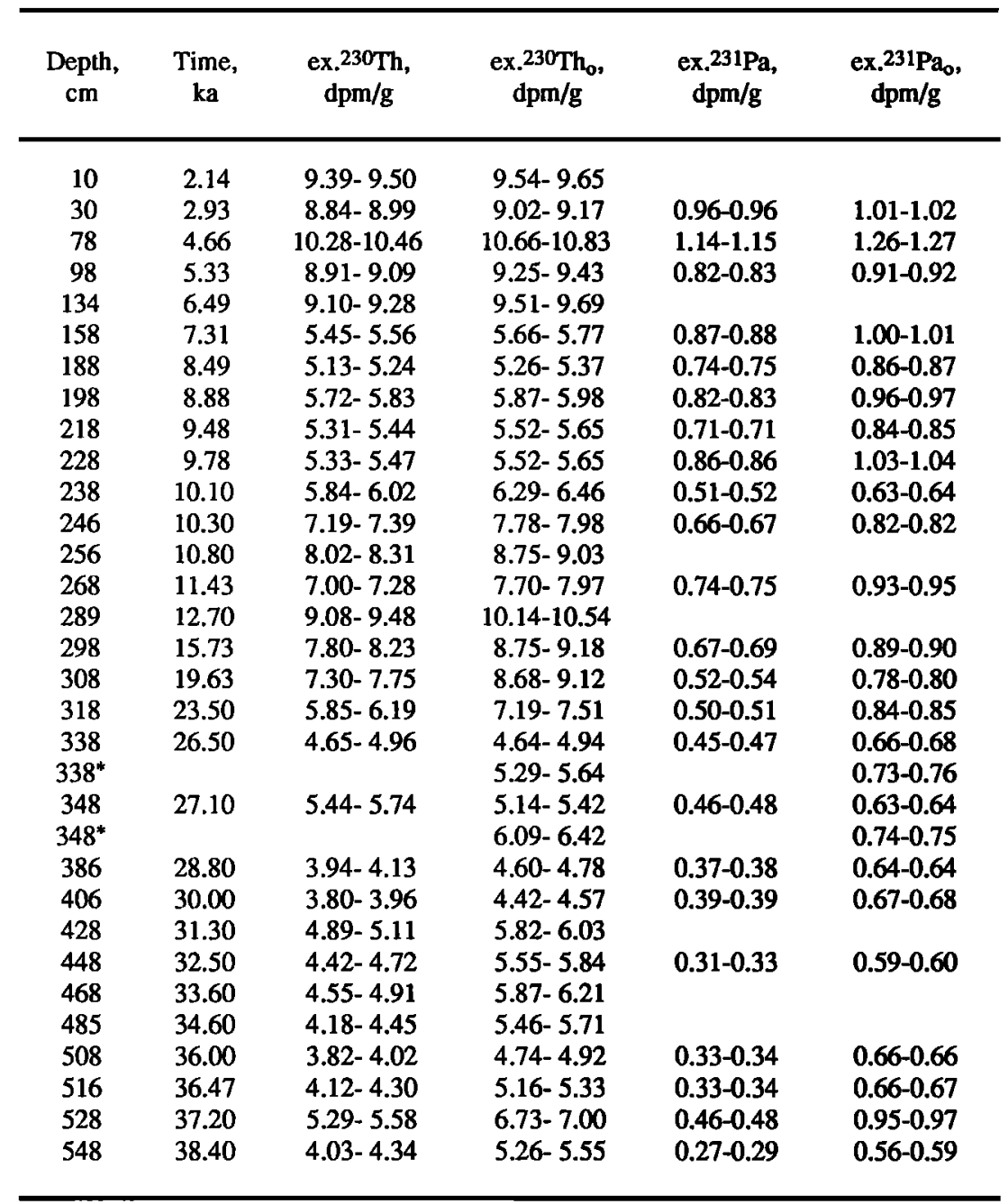

* Excess ${ }^{230} \mathrm{Th} \mathrm{h}_{\mathrm{o}}$ and excess ${ }^{231} \mathrm{~Pa}_{\mathrm{o}}$ computed with the assumption that authigenic $\mathrm{U}$ was added to these sediment sections at $14 \mathrm{ka} \mathrm{B.P.} \mathrm{(see} \mathrm{text} \mathrm{for} \mathrm{explanations).}$

(ex. ${ }^{230} \mathrm{Th}$ ) $; A_{3}$ is the ${ }^{230} \mathrm{Th}$ not supported by detrital ${ }^{238} \mathrm{U}$ (ex. ${ }^{230} \mathrm{Th}$ ); $A_{1}{ }^{\circ}$ is the activity of authigenic ${ }^{238} \mathrm{U} ; A_{2}{ }^{\circ}$ is the activity of authigenic ${ }^{234} \mathrm{U}$ initially added to the sediment (i.e., $\left.1.14 \times A_{1}{ }^{\circ}\right) ; \lambda 2$ and $\lambda 3$ are the decay constants of ${ }^{234} U$ and ${ }^{230}$ Th respectively; and $t$ is the age of the sediment.

If authigenic $U$ has diffused from the overlying seawater into the sediment along a pore water gradient [Cochran and Krishnaswami, 1980; Barnes and Cochran, 1990;

Klinkhammer and Palmer, 1991], then the assumption that authigenic $U$ was added at the time of sediment deposition is not correct. However, as we will show later, in order to sustain the authigenic $U$ burial rates measured in this core, the $U$ reduction zone would have to be within $30 \mathrm{~cm}$ of the sediment water interface. Considering the high sediment accumulation rates measured throughout most of this core, the error associated with our initial assumption must be less than
2000 years (except for sediment deposited during isotope stage 2 and the close of isotopic stage 3 - see below), which is small compared to the 75,200-year half-life of ${ }^{230} \mathrm{Th}$.

Measured total ${ }^{230}$ Th activities (Table 1) and decay/ingrowthcorrected excess ${ }^{230}$ Th activities based on the above assumption (Table 3) are shown in Figure 3b.

Protactinium-231

As for ${ }^{230} \mathrm{Th}$, the calculation of ${ }^{231} \mathrm{~Pa}$ scavenged by sediment from the water column (ex. $\left[{ }^{231} \mathrm{~Pa}\right]_{0}$ ) requires correction for lattice-held ${ }^{231} \mathrm{~Pa}$ (supported by lattice-held ${ }^{235} \mathrm{U}$ ), decay since the time of deposition and ingrowth from authigenic ${ }^{235} \mathrm{U}$. The following equation was used:

$A_{5}{ }^{\circ}=A_{5} e^{\lambda 5 . t}-A_{4}{ }^{\circ}\left(e^{\lambda 5 . t}-1\right)$

where $A_{5}{ }^{\circ}$ is the decay- and ingrowth-corrected ${ }^{231} \mathrm{~Pa}$ activity; 


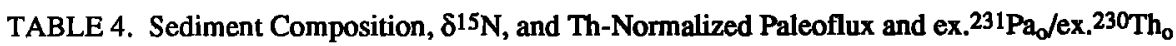
Activity Ratio in Core MD84-527

\begin{tabular}{|c|c|c|c|c|c|c|c|c|}
\hline \multirow{2}{*}{$\begin{array}{l}\text { Depth, } \\
\mathrm{cm}\end{array}$} & \multirow{2}{*}{$\begin{array}{c}\text { Time, } \\
\text { ka }\end{array}$} & \multicolumn{3}{|c|}{ Fraction } & \multirow{2}{*}{$\underset{\%}{\Sigma \mathrm{N}}$} & \multirow{2}{*}{$\begin{array}{l}\delta 15 \mathrm{~N}, \\
\text { permil }\end{array}$} & \multirow{2}{*}{$\begin{array}{l}\text { Total Flux, } \\
\mathrm{g} / \mathrm{cm}^{-2} \mathbf{k a}^{-1}\end{array}$} & \multirow{2}{*}{$\frac{\mathrm{ex}^{231} \mathrm{~Pa}_{0}}{\mathrm{ex}^{230} \mathrm{Th}_{\mathrm{o}}}$} \\
\hline & & $\overline{\mathrm{CaCO}_{3}}$ & Opal & Terrigenous & & & & \\
\hline 10 & 2.14 & 0.23 & 0.60 & 0.17 & 0.090 & 4.2 & $0.89-0.90$ & $0.111-0.112$ \\
\hline 20 & 2.54 & 0.17 & & & 0.084 & 4.0 & & \\
\hline 30 & 2.93 & 0.27 & 0.56 & 0.17 & 0.079 & 4.5 & $0.94-0.95$ & $0.117-0.118$ \\
\hline 58 & 3.94 & 0.25 & & & 0.082 & 4.7 & & \\
\hline 78 & 4.66 & 0.26 & 0.52 & 0.22 & 0.077 & 4.9 & $0.79-0.81$ & $0.098-0.099$ \\
\hline 98 & 5.33 & 0.26 & 0.46 & 0.28 & 0.073 & 4.9 & $0.91-0.93$ & \\
\hline 134 & 6.49 & 0.31 & 0.51 & 0.18 & 0.073 & 5.0 & $0.89-0.90$ & \\
\hline 148 & 6.97 & 0.26 & & & 0.071 & 4.9 & & \\
\hline 158 & 7.31 & 0.28 & 0.59 & 0.14 & 0.075 & 4.5 & $1.49-1.52$ & $0.175-0.177$ \\
\hline 168 & 7.71 & 0.21 & & & 0.080 & 4.7 & & \\
\hline 178 & 8.10 & 0.23 & & & 0.083 & 4.8 & & \\
\hline 188 & 8.49 & 0.20 & 0.57 & 0.23 & 0.110 & 4.6 & $1.60-1.63$ & $0.162-0.164$ \\
\hline 198 & 8.88 & 0.28 & 0.56 & 0.16 & 0.084 & 4.6 & $1.44-1.46$ & $0.162-0.164$ \\
\hline 208 & 9.18 & 0.28 & & & 0.085 & 4.3 & & \\
\hline 218 & 9.48 & 0.26 & 0.56 & 0.18 & 0.077 & 4.5 & $1.52-1.56$ & $0.150-0.153$ \\
\hline 228 & 9.78 & 0.29 & 0.54 & 0.17 & 0.045 & 4.5 & $1.52-1.56$ & $0.183-0.187$ \\
\hline 238 & 10.10 & 0.31 & 0.49 & 0.20 & 0.049 & 5.0 & $1.33-1.37$ & $0.098-0.100$ \\
\hline 246 & 10.30 & 0.39 & 0.36 & 0.25 & 0.048 & 5.1 & $1.08-1.10$ & $0.103-0.105$ \\
\hline 256 & 10.80 & 0.37 & 0.37 & 0.26 & 0.061 & 6.1 & $0.95-0.98$ & \\
\hline 268 & 11.43 & 0.22 & 0.51 & 0.27 & 0.054 & 6.2 & $1.08-1.12$ & $0.119-0.121$ \\
\hline 289 & 12.70 & 0.27 & 0.33 & 0.40 & 0.053 & 6.4 & $0.82-0.85$ & \\
\hline 298 & 15.73 & 0.15 & 0.39 & 0.46 & 0.062 & 6.3 & $0.94-0.98$ & $0.099-0.101$ \\
\hline 308 & 19.63 & 0.12 & 0.42 & 0.46 & 0.065 & 6.2 & $0.94-0.99$ & $0.086-0.090$ \\
\hline 318 & 23.50 & 0.13 & 0.47 & 0.40 & 0.040 & 5.4 & $1.14-1.20$ & $0.114-0.117$ \\
\hline 328 & 25.65 & 0.14 & & & 0.081 & 5.3 & & \\
\hline 338 & 26.50 & 0.12 & 0.49 & 0.39 & 0.076 & 4.5 & $1.74-1.85$ & $0.138-0.142$ \\
\hline $338^{*}$ & & & & & & & $1.53-1.63$ & $0.135-0.139$ \\
\hline 348 & 27.10 & 0.14 & 0.47 & 0.39 & 0.068 & 5.0 & $1.59-1.67$ & $0.118-0.122$ \\
\hline $348^{*}$ & & & & & & & $1.34-1.41$ & $0.116-0.122$ \\
\hline 358 & 27.55 & 0.13 & & & 0.072 & 5.3 & & \\
\hline 368 & 27.99 & 0.17 & & & 0.068 & 4.6 & & \\
\hline 386 & 28.80 & 0.15 & 0.62 & 0.23 & 0.055 & 5.0 & $1.80-1.87$ & $0.135-0.138$ \\
\hline 406 & 30.00 & 0.14 & 0.68 & 0.18 & 0.078 & 4.6 & $1.88-1.95$ & $0.149-0.152$ \\
\hline 428 & 31.30 & 0.22 & 0.57 & 0.21 & 0.071 & 5.1 & $1.43-1.48$ & \\
\hline 448 & 32.50 & 0.08 & 0.62 & 0.30 & 0.062 & 5.1 & $1.47-1.55$ & 0103-0105 \\
\hline 468 & 33.60 & 0.18 & 0.54 & 0.28 & 0.065 & 5.1 & $1.38-1.47$ & \\
\hline 478 & 34.19 & 0.08 & & & 0.072 & 5.1 & & \\
\hline 485 & 34.60 & 0.17 & 0.58 & 0.25 & 0.061 & 4.9 & $1.51-1.58$ & \\
\hline 498 & 35.39 & 0.12 & & & 0.067 & 5.0 & & \\
\hline 508 & 36.00 & 0.14 & 0.66 & 0.20 & 0.073 & 4.8 & $1.75-1.82$ & $0135-0138$ \\
\hline 516 & 36.47 & 0.14 & 0.65 & 0.21 & 0.058 & 5.0 & $1.61-1.67$ & $0126-0129$ \\
\hline 528 & 37.20 & 0.21 & 0.52 & 0.27 & 0.058 & 5.3 & $1.23-1.28$ & $0138-0142$ \\
\hline 548 & 38.40 & 0.16 & 0.57 & 0.27 & 0.050 & 5.6 & $1.55-1.64$ & 0106-0107 \\
\hline
\end{tabular}

* Paleofluxes and ex. ${ }^{231} \mathrm{~Pa}_{0} / \mathrm{ex}^{230} \mathrm{Th}_{\mathrm{o}}$ activity ratios computed with the assumption that authigenic $\mathrm{U}$ was added to these sediment sections at 14 ka B.P. (see text for explanations). 
$A_{5}$ is the ${ }^{231} \mathrm{~Pa}$ not supported by detrital ${ }^{235} \mathrm{U} ; A_{4}{ }^{\circ}$ is the activity of authigenic ${ }^{235} \mathrm{U} ; \lambda 5$ is the decay constant of ${ }^{231} \mathrm{~Pa}$. Detrital and authigenic ${ }^{235} \mathrm{U}$ were estimated from ${ }^{238} \mathrm{U}$ activities (i.e., $\left.{ }^{235} \mathrm{U}(\mathrm{dpm} / \mathrm{g})={ }^{238} \mathrm{U}(\mathrm{dpm} / \mathrm{g}) \times 0.045\right)$. The results of these calculations are shown in Table 3 .

\section{Sediment $\delta^{15} \mathrm{~N}$}

Bulk sediment $\delta^{15} \mathrm{~N}$ was relatively low (circa 5 per mil) prior to $25 \mathrm{kyr}$ B.P., increased by circa 1.5 per mil during the last glacial maximum, remained higher than 6 per mil throughout deglaciation, and decreased abruptly to circa 4.5 per mil at $10 \mathrm{kyr}$ B. P. (Table 4).

\section{DISCUSSION}

\section{Thorium 230 Normalized Paleofluxes}

Application of equation (1) to ex. $\left[{ }^{230} \mathrm{Th}\right]_{0}$ data reveals relatively high but variable rain rates during isotopic stage 3 , relatively low fluxes during isotopic stage 2 and deglaciation, followed by a prominent maximum during early Holocene, centered at circa 9 kyr B.P. (Table 4, Figure 4).

Sediment composition (Table 4) indicates that the high flux periods are mainly due to increased opal rain rate (Figure 4), and presumably higher production in the overlying surface waters. Low opal fluxes recorded during isotopic stage 2 could also reflect higher opal dissolution due to lower sediment accumulation rates. However, estimates of opal dissolution from a diatom transfer function [Pichon et al., 1992] did not reveal any clear increase in opal dissolution for

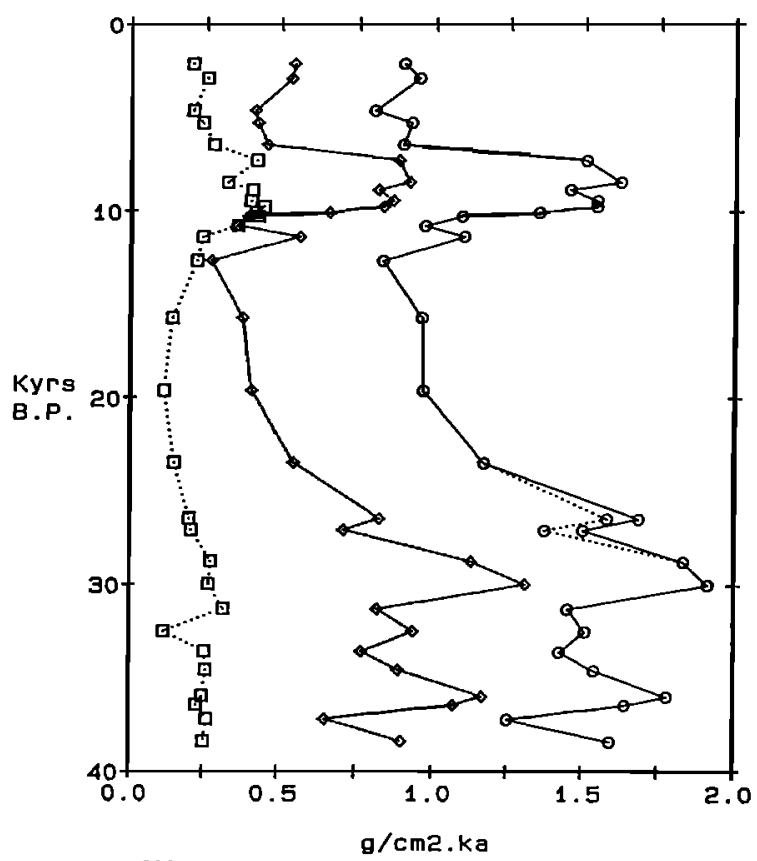

Fig. 4. Ex. ${ }^{230}$ Th-normalized fluxes (circles, total; diamonds, opal; squares, carbonate). Circles connected by dotted line are total paleoflux assuming that authigenic $U$ found in this core section was added at $14 \mathrm{ka} \mathrm{B.P.} \mathrm{(see} \mathrm{text} \mathrm{for} \mathrm{explanations).}$

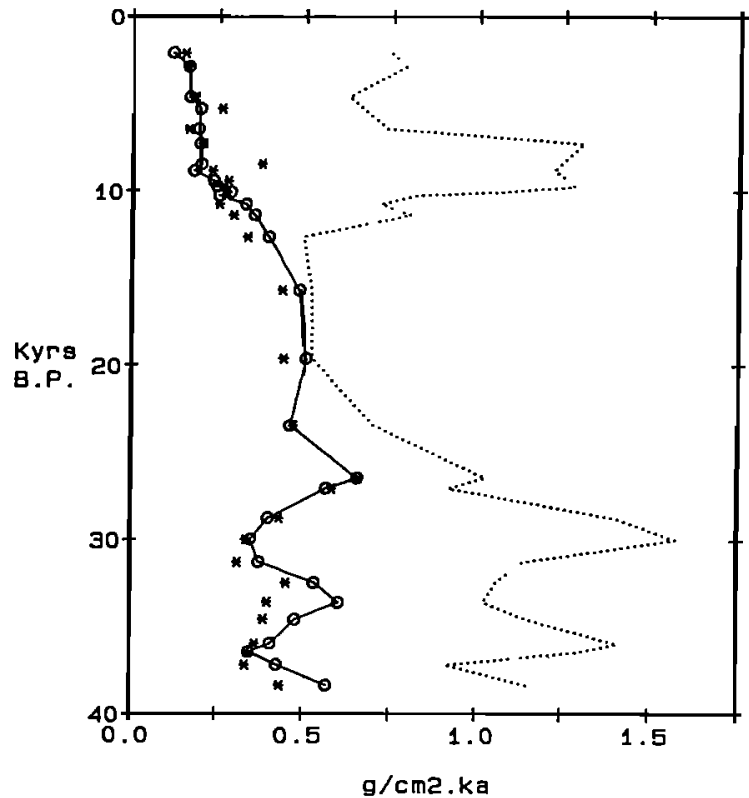

Fig. 5. Ex. ${ }^{230}$ Th-normalized fluxes. Circles: terrigenous fluxes estimated from ${ }^{232} \mathrm{Th}$ fluxes and an average $1.7 \mathrm{dpm} / \mathrm{g}$ ${ }^{232} \mathrm{Th}$ activity in the detrital fraction of the sediment.

Asterisks: terrigenous fluxes calculated by difference (total carbonate - opal). Dotted line: biogenic fluxes (opal plus carbonate).

that period [Bareille, 1991]. Our opal rain rate estimates fall within the range of Holocene opal accumulation rates $(0.1$ to $1.5 \mathrm{~g} / \mathrm{cm}^{2} \mathrm{kyr}$ ) measured in a series of box cores collected north of the Polar Frontal Zone, which had been taken on a relatively shallow ridge (Southeast Indian Ridge) to limit the influence of syndepositional sediment redistribution [Bareille et al., 1991]. The Holocene maximum is also associated with high carbonate fluxes which peaked just prior to the opal maximum (Figure 4).

In contrast to biogenic fluxes, terrigenous fluxes (calculated by difference or estimated from ${ }^{232} \mathrm{Th}$ fluxes), which are also relatively high and variable during isotopic stage 3 , remain high during stage 2 and gradually decrease during deglaciation to low Holocene values (Figure 5). This is a pattern very similar to that observed in the equatorial Atlantic [Francois and Bacon, 1991]. This observation was attributed to higher fluvial input into the deep-sea during periods of lowered sea level, as rivers were able to flow across the continental shelves and discharge their load directly into deep water. This effect appears still to be measurable in this area which is far removed from any important river systems, although in this region, the higher detrital input during the glacial could also reflect the influence of ice-rafted debris [Labeyrie et al., 1986], or originate from the Crozet Plateau during low sea level stand [Bareille, 1991]. The terrigenous flux pattern is also reminiscent of the dust record in ice cores [Petit et al., 1990], suggesting that the detrital phase found in this sediment may be partly eolian. The terrigenous flux recorded in this core, however, is 3 orders of magnitude higher than that recorded in the Vostok ice core $(0.1$ to $1 \mathrm{mg}$ 
$\mathrm{cm}^{-2} \mathrm{kyr}^{-1}$ ), which indicates either that eolian material contitutes an insignificant fraction of the detrital phase of southern ocean sediment or that the dust flux near $40^{\circ}-50^{\circ} \mathrm{S}$, at sea level, was much higher than recorded at the Vostok site.

Ex. $\left.{ }^{231} \mathrm{~Pa}\right]_{o} / \mathrm{Ex} .\left[^{230} \mathrm{Th}\right]_{O}$ Profile

Maxima in ex. $\left[{ }^{231} \mathrm{~Pa}\right]_{0} / \mathrm{ex} .\left[{ }^{230} \mathrm{Th}\right]_{0}$ coincide with maxima in paleofluxes (Figure 6). The sediment ratios are similar to the production rate ratio $(0.093)$ at the minima but increase to values as high as 0.185 during the early Holocene (Table 4).

Data from year-long sediment trap deployments in the deep sea indicate that, unlike ${ }^{230} \mathrm{Th},{ }^{231} \mathrm{~Pa}$ flux to the seafloor increases significantly as total mass flux increases (E.-F. Yu, unpublished data, 1993). This is a reflection of the lower particle reactivity of ${ }^{231} \mathrm{~Pa}$ and its longer residence time in the water column, which enables it to be more effectively transported laterally before scavenging. This translates into higher ${ }^{231} \mathrm{~Pa}$ fluxes compared to ${ }^{230} \mathrm{Th}$ in areas of higher settling fluxes [Anderson et al., 1983; Bacon, 1988, Anderson et al., 1990]. Higher ex. $\left[{ }^{231} \mathrm{~Pa}\right]_{0} / \mathrm{ex}\left[{ }^{230} \mathrm{Th}\right]_{0}$ thus confirms that the higher paleofluxes deduced from ${ }^{230}$ Th normalization reflect higher rain rates (and thus higher efficiency for the scavenging of particle-reactive metals) from the overlying water column.

The paleoflux maxima of isotopic stage 3 reach slightly higher values $\left(1.75-1.95 \mathrm{~g} \mathrm{~cm}^{-2} \mathrm{kyr}^{-1}\right)$ than the Holocene maximum $\left(1.6 \mathrm{~g} \mathrm{~cm}^{-2} \mathrm{kyr}^{-1}\right)$, but ex. $\left[{ }^{231} \mathrm{~Pa}\right]_{\mathrm{o}} / \mathrm{ex}\left[{ }^{230} \mathrm{Th}\right]_{0}$ values are comparatively higher during the early Holocene event (Figure 6). Enhanced ${ }^{231} \mathrm{~Pa}$ scavenging depends not only on the local intensity of scavenging but also on the degree of scavenging in surrounding oceanic regions with lower particle flux, which must act as sources for the excess ${ }^{231} \mathrm{~Pa}$. Thus the comparatively high ${ }^{231} \mathrm{~Pa} /{ }^{230} \mathrm{Th}$ activity

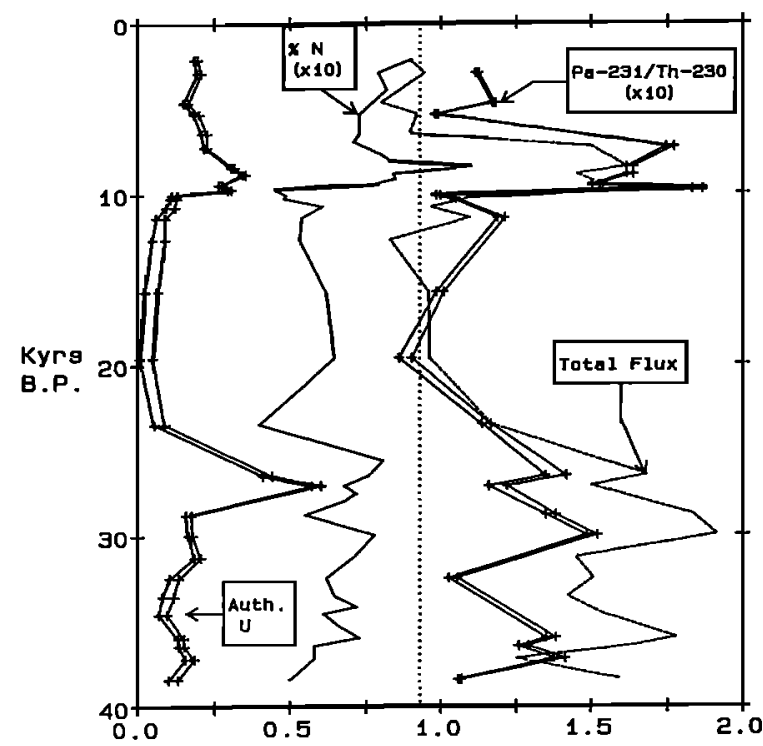

Fig. 6. Authigenic U activities (dpm/100 mg), \% nitrogen (x10), ex. ${ }^{231} \mathrm{~Pa} / \mathrm{ex} .{ }^{230} \mathrm{Th}$ ratio (x10) and total normalized flux $\left(\mathrm{g} / \mathrm{cm}^{-2} \mathrm{ka}^{-1}\right)$. The vertical dotted line represents the ${ }^{231} \mathrm{~Pa} /{ }^{230} \mathrm{Th}$ production ratio $(\mathrm{x} 10)$ in seawater. ratios of the early Holocene suggest that the high rain rate recorded at that time was a relatively localized event. In contrast, the stage 3 maxima may be a reflection of increased opal production over a broader region. Higher particle flux in surrounding areas would have prevented the accumulation of a large ${ }^{231} \mathrm{~Pa}$ inventory at the site. Further data from other cores in the region are necessary to confirm this.

\section{Authigenic U Profile}

The authigenic $U$ profile displays two distinct maxima, one centered near the $9 \mathrm{kyr}$ B.P. horizon and the second occurring at the close of isotopic stage 3 (Table 2, Figure 6).

Authigenic $U$ could have been added to the sediment as a result of more reducing conditions in the sediment produced by higher settling flux of planktonic debris [Cochran and Krishnaswami, 1980; Barnes and Cochran, 1990; Klinkhammer and Palmer, 1991]. The abrupt increase in authigenic $U$ at circa $10 \mathrm{kyr}$ B.P. coincides with the sharp increase in ${ }^{230} \mathrm{Th}$-normalized paleoflux and ${ }^{231} \mathrm{~Pa} /{ }^{230} \mathrm{Th}$ ratio discussed above. It is therefore consistent with our interpretation of these profiles as reflections of higher rain rates of biogenic materials from the overlying water column. At the same depth, we also observe an increase in $\% \mathrm{~N}$ (Figure 6), also supporting the view that this $U$ maximum reflects a higher flux of organic matter at that time. A similar pattern, with higher ${ }^{238} \mathrm{U} /{ }^{232} \mathrm{Th}$ activity ratios in interglacial sediments deposited during periods of higher productivity, was also observed in the Labrador Sea [Hillaire-Marcel et al., 1990]. On the other hand, the more prominent authigenic U peak centered at $27 \mathrm{kyr}$ B.P. does not appear to be associated with a clear maximum in $\% \mathrm{~N},{ }^{230} \mathrm{Th}$-normalized paleoflux or ${ }^{230} \mathrm{Th} /{ }^{231} \mathrm{~Pa}$ ratio and must have arisen through a different mechanism.

In sediments with constant accumulation rate, higher authigenic $U$ concentrations suggest a shoaling of the depth of the sedimentary horizon where $U$ is reduced and removed to the solid phase, resulting in steeper pore water $U$ concentration gradients. If we assume, as a first approximation, a linear pore water gradient from seawater concentration at the sediment-water interface $\left(1.3 \times 10^{-11} \mathrm{~mol}\right.$ $\mathrm{cm}^{-3}$ ) to $0 \mathrm{~mol} \mathrm{~cm} \mathrm{~cm}^{-3}$ at the depth of $U$ reduction, we can estimate the depth at which $U$ must be reduced in order to produce the $U$ concentration gradient required to sustain the measured authigenic $U$ accumulation rates.

We know the accumulation rate of authigenic $U(F U)$ :

$F_{U}\left(\right.$ mole cm $\left.^{-2} \mathrm{~s}^{-1}\right)=S \times \rho \times[U]$

where

$S \quad$ sediment accumulation rate at the time of $\mathbf{U}$ deposition $\left(\mathrm{cm} \mathrm{s}^{-1}\right)$

$\rho \quad$ dry bulk density $\left(\mathrm{g} \mathrm{cm}^{-3}\right)$;

$[U] \quad U$ concentration in sediment $\left(\mathrm{mol} \mathrm{g}^{-1}\right)$.

Note that $S$ is not the accumulation rate of the sediment in which $U$ is found, but instead is the accumulation rate of the sediment deposited later, at the time of addition of authigenic $\mathrm{U}$ after diffusion along its pore water concentration gradient. FU must also equal the diffusive flux of $U$ along the pore water gradient, i.e., 


$$
F_{U}\left(\mathrm{~mol} \mathrm{~cm}^{-2} \mathrm{~s}^{-1}\right)=\frac{D \times C_{i}}{z_{U}}
$$

where

D pore water diffusion coefficient for $\mathrm{U}\left(3 \times 10^{-6}\right.$

$\mathrm{cm}^{2} \mathrm{~s}^{-1} ;$ Klinkhammer and Palmer, [1991]);
$C_{i} \quad$ concentration of $U$ in seawater $\left(1.3 \times 10^{-11} \mathrm{~mol} \mathrm{~cm}^{-3}\right)$;

$z_{U} \quad$ depth of the $U$ reduction zone below the contemporary sediment-water interface $(\mathrm{cm})$.

Hence

$z_{U}=\frac{D \times C_{i}}{S \times \rho \times[U]}$

Besides changes in pore water $U$ concentration gradients, variations in sediment accumulation rates can also produce changes in authigenic $U$ concentration, as a sediment subjected to a given diffusive flux will accumulate more authigenic $\mathrm{U}$ at lower sediment accumulation rate [e.g., Klinkhammer and Palmer, 1991]. Sediment accumulation rates in core MD84-527 are not constant. Instead, they decrease abruptly at circa $25 \mathrm{kyr}$ B.P., and increase again around $13 \mathrm{kyr}$ B.P. (Figure 2). Therefore, the prominent authigenic $U$ peak at the close of isotopic stage 3 could result from the sharp decrease in sediment accumulation rate during isotopic stage 2 .

In the following, we attempt to reconstruct past variations in the depth of the $U$ reducing zone ( $\mathrm{zU}$ ), taking into account changes in authigenic $U$ concentration and sediment accumulation rate. We start with the sediment deposited during isotopic stage 3 . Because sediment accumulation appears relatively constant during that period (Figure 2), we use $S=17 \mathrm{~cm} \mathrm{kyr}^{-1}$ to compute $F_{U}$ (Table 5). Dry bulk density ( $\rho$ ) was estimated from the relationship between $\%$ $\mathrm{CaCO}_{3}$ and dry bulk density found by Froelich et al. [1991] for southern ocean sediments $\left(\rho=5.31310^{-5} \times\left[\mathrm{CaCO}_{3}\right]^{2}+\right.$

TABLE 5. Flux of Authigenic U Into the Sediment $\left(F_{U}\right)$, Depth of the $U$ Reducing Zone Below the Sediment-Water Interface $\left(\mathrm{z}_{U}\right)$, and Time of Authigenic $U$ Deposition $\left(\mathrm{T}_{\mathrm{U}}\right)$

\begin{tabular}{|c|c|c|c|c|c|c|}
\hline $\begin{array}{l}\mathrm{Z} \\
\mathrm{cm}\end{array}$ & $\begin{array}{l}\text { Time, } \\
\text { ka }\end{array}$ & $\begin{array}{c}\text { Authigenic }{ }^{238} \mathrm{U} \text {, } \\
\text { ppm }\end{array}$ & $\begin{array}{c}\mathrm{F}_{\mathrm{U}} \\
\mathrm{mg} / \mathrm{cm}^{-2} \mathbf{k a}^{-1}\end{array}$ & $\begin{array}{l}\mathrm{z}_{\mathrm{U}} \\
\mathbf{c m}\end{array}$ & $\begin{array}{l}\mathrm{z}_{\mathrm{s}}^{*}, \\
\mathrm{~cm}\end{array}$ & $\underset{\mathbf{k a}}{\mathrm{T}_{\mathrm{U}}^{*},}$ \\
\hline 10 & 2.14 & $2.62-2.48$ & $26.1-27.6$ & $8.1-8.6$ & 1.6 & 0.1 \\
\hline 30 & 2.93 & $2.81-2.61$ & $27.5-29.6$ & 7.6- 8.2 & 22 & 0.8 \\
\hline 78 & 4.66 & $2.24-2.00$ & $21.1-23.5$ & $9.6-10.7$ & 68 & 2.5 \\
\hline 98 & 5.33 & $2.71-2.47$ & $26.0-28.5$ & $7.9-8.7$ & 90 & 3.4 \\
\hline 134 & 6.49 & $3.08-2.84$ & 29.9-32.4 & $6.9-7.5$ & 127 & 4.8 \\
\hline 158 & 7.31 & $3.08-2.93$ & $30.8-32.4$ & $6.9-7.3$ & 151 & 5.7 \\
\hline 188 & 8.49 & $4.28-4.14$ & $43.6-45.1$ & $5.0-5.2$ & 183 & 6.9 \\
\hline 198 & 8.88 & $4.79-4.65$ & $49.0-50.5$ & $4.5-4.6$ & 194 & 7.3 \\
\hline 218 & 9.48 & $3.76-3.58$ & $37.7-39.6$ & $5.7-6.0$ & 212 & 8.0 \\
\hline 228 & 9.78 & $4.17-3.99$ & $42.0-43.9$ & $5.1-5.4$ & 223 & 8.3 \\
\hline 238 & 10.10 & $1.74-1.50$ & $15.7-18.3$ & $12.3-14.3$ & 225 & 8.4 \\
\hline 246 & 10.30 & $1.72-1.46$ & $15.4-18.1$ & $12.4-14.7$ & 233 & 8.7 \\
\hline 256 & 10.80 & $1.64-1.25$ & $13.2-17.3$ & $13.0-17.0$ & 241 & 9.0 \\
\hline 268 & 11.43 & $1.20-0.83$ & $8.7-12.6$ & $17.8-25.7$ & 246 & 9.2 \\
\hline 289 & 12.70 & $1.20-0.66$ & $6.9-12.7$ & $17.7-32.4$ & 264 & 9.9 \\
\hline 298 & 15.73 & $0.91-0.33$ & $3.5-9.6$ & $23.5-65.0$ & - & $(10.0)$ \\
\hline 308 & 19.63 & $0.67-0.11$ & $1.1-7.1$ & $31.8-203$ & - & (10.5) \\
\hline 318 & 23.50 & $1.19-0.75$ & $7.9-12.6$ & $17.8-28.6$ & - & - \\
\hline 338 & 26.50 & $5.98-5.56$ & $5.0-5.4$ & $41.8-45.0$ & 295 & 11.1 \\
\hline 348 & 27.10 & $8.12-7.72$ & $7.0-7.3$ & $30.8-32.4$ & 316 & $13-25$ \\
\hline 386 & 28.80 & $2.35-2.10$ & $12.9-14.4$ & $15.6-17.5$ & 369 & 28.0 \\
\hline 406 & 30.00 & $2.43-2.22$ & $13.6-14.8$ & $15.2-16.6$ & 390 & 29.0 \\
\hline 428 & 31.30 & $2.79-2.49$ & 15.3-17.1 & $13.2-14.7$ & 414 & 30.4 \\
\hline 448 & 32.50 & $1.82-1.41$ & $8.6-11.1$ & $20.3-26.1$ & 425 & 31.0 \\
\hline 468 & 33.60 & $1.58-1.09$ & $6.7-9.7$ & $23.3-33.6$ & 440 & 31.9 \\
\hline 485 & 34.60 & $1.28-0.92$ & $5.6-7.8$ & $28.7-39.9$ & 451 & 32.5 \\
\hline 508 & 36.00 & $2.04-1.77$ & $10.9-12.5$ & $18.1-20.7$ & 489 & 34.7 \\
\hline 516 & 36.47 & $2.06-1.82$ & $11.1-12.6$ & $17.8-20.2$ & 497 & 35.2 \\
\hline 528 & 37.20 & $2.50-2.11$ & $12.9-15.3$ & $14.7-17.4$ & 512 & 36.1 \\
\hline 548 & 38.40 & $1.76-1.35$ & $8.3-10.8$ & $20.8-27.2$ & 524 & 36.8 \\
\hline
\end{tabular}

* $T_{U}$ was computed from $\mathrm{z}_{\mathrm{s}}$ obtained by substracting $\mathrm{z}_{\mathrm{U}}$ (averaged) from the depth at which $\mathrm{U}$ was found (Z). 
9.346 $\left.10^{-4} \times\left[\mathrm{CaCO}_{3}\right]+0.3367\right)$. Applying equation (6) yields a depth of circa 10 to $30 \mathrm{~cm}$ below the sediment water interface for the $U$ reducing zone (Figure 7, Table 5). Therefore authigenic $U$ found in sediment deposited during late isotopic stage 3 (i.e., circa $15-20 \mathrm{~cm}$ below stage $2 / 3$ boundary) must have been added during isotopic stage 2 . The high $U$ concentration found in this core section (Figures 3a and 6) is a result of the low sediment accumulation rate prevailing during the last glacial maximum, which enabled more authigenic $U$ to accumulate in the underlying sediment. For this core section, we use $S=2.5 \mathrm{~cm} \mathrm{kyr}^{-1}$ for the calculation of $\mathrm{F}_{\mathrm{U}}$, resulting in $\mathrm{z}_{\mathrm{U}}>30 \mathrm{~cm}$ (Table 5, Figure 7). This situation complicates the computation of ex. ${ }^{230} \mathrm{Th}_{\mathrm{O}}$, ex. ${ }^{231} \mathrm{~Pa}_{0}$ and associated paleofluxes in this core section, because the assumption that authigenic $U$ was added shortly after sediment deposition is violated. Ex. ${ }^{230} \mathrm{Th}_{\mathrm{O}}$ and ex. ${ }^{231} \mathrm{~Pa}_{\mathrm{o}}$ must have been overcorrected for ingrowth and thus must be taken as minimum values. The actual $e x^{230} \mathrm{Th}_{\mathrm{O}}$ and ex. ${ }^{231} \mathrm{~Pa}_{0}$ activities can be bracketed by assuming that all the authigenic $U$ found in this core section was added at the close of isotopic stage 2, i.e., approximately 14,000 years after sediment deposition. This calculation results in a decrease in paleoflux and ex. ${ }^{230} \mathrm{Th}_{\mathrm{o}} / \mathrm{ex} .{ }^{231} \mathrm{~Pa}_{\mathrm{O}}$ activity ratio but does not affect the conclusions (Figure 4, Tables 3 and 4).

Estimates of $\mathrm{z}_{U}$ during isotopic stage 2 and Holocene (Table 5 , Figure 7) indicate that authigenic $U$ found in sediment

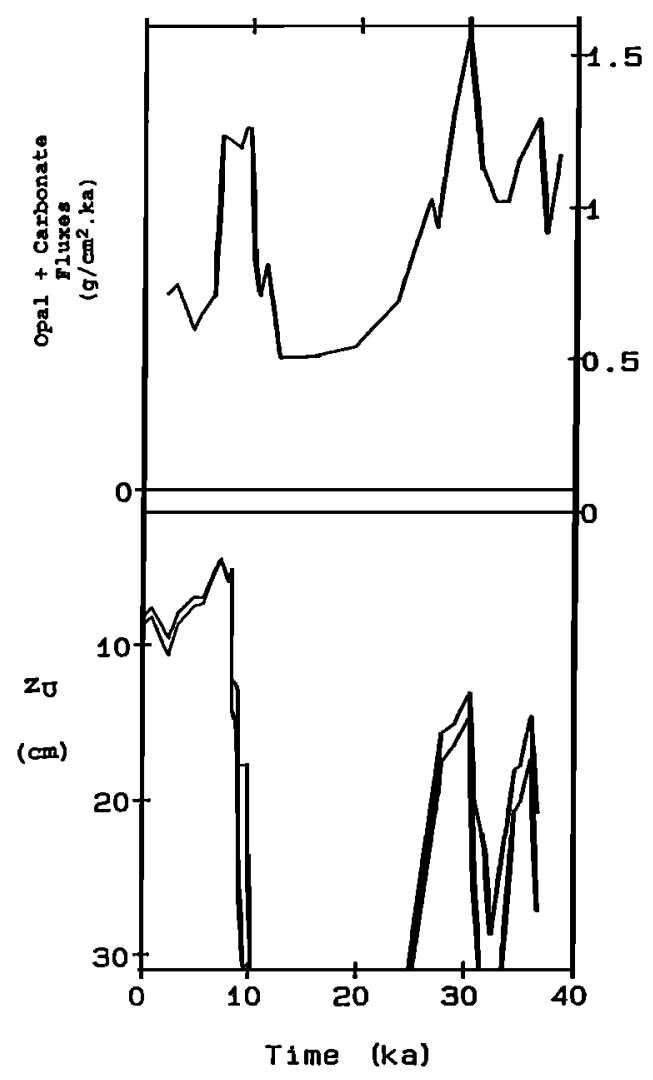

Fig. 7. Comparison between biogenic fluxes (opal + carbonate) and estimates of the depth of $U$ reduction zone within the sediment $\left(\mathbf{z}_{U}\right)$. deposited during the last glacial period was added during deglaciation. This also violates the assumption underlying ex. ${ }^{230} \mathrm{Th}_{\mathrm{O}}$ and ex. ${ }^{231} \mathrm{~Pa}_{\mathrm{o}}$ activity calculations. However, stage 2 sediment contain very little authigenic $U$ (Figures $3 a$ and 6), as a result of small $U$ pore water gradients (i.e., large $\mathrm{z}_{U}$ ) and high sediment accumulation rates at the onset of deglaciation (Figure 2). The error produced by assuming simultaneous deposition of authigenic $U$ and associated sediment is thus negligible for this core section.

Estimates of $z_{U}$ for the last 38,000 years are compared to biogenic paleofluxes (i.e., opal plus carbonate) in Figure 7. There is a correlation between $z_{U}$ and biogenic fluxes, with relatively shallow $U$ reducing zones coinciding with periods of high biogenic fluxes and presumably higher production in the overlying water. During the Holocene, for instance, the depth of the $U$ reduction zone might have risen to as close as $5 \mathrm{~cm}$ below the sediment-water interface during the period of maximum paleoflux and maximum ${ }^{231} \mathrm{~Pa}$ scavenging. A similar correlation is observed during isotopic stage 3 with the biogenic paleoflux maxima (mainly opal) centered at 30 and $36 \mathrm{kyr}$ B.P. On the other hand, the prominent authigenic $U$ activity maximum centered around $27 \mathrm{kyr}$ B.P. is not associated with a shoaling of $\mathrm{z}_{\mathrm{U}}$, because it is in large part produced by the dramatic decrease in sediment accumulation rate occurring during isotopic stage 2 , which subjected this sediment section to the same $U$ diffusive flux for a longer period of time. Estimates of $\mathrm{z}_{U}$ during the last glacial period suggest a very deep $\mathrm{U}$ reducing zone (up to circa $1 \mathrm{~m}$; Table 5). This raises the possibility that some of the suboxic sediment deposited at the close of isotopic stage 3 might have been eroded by a deepening oxic front during stage 2 , resulting in the remobilization of some of the initially deposited authigenic $U$ to greater depth, in a pattern similar to that observed in Atlantic turbidites [Colley et al., 1989]. The authigenic $U$ maximum found at $348 \mathrm{~cm}$ could thus also be partly the result of the deepening of the redox front during isotopic stage 2.

The correlation between biogenic paleoflux and $\mathrm{z}_{\mathrm{U}}$ is not perfect. This is particularly true for the last 6000 years when $\mathrm{z}_{U}$ deepened only slightly while biogenic fluxes decreased by a factor of two. Also, at equal biogenic flux, $z_{U}$ tends to be deeper during isotopic stage 3 than during the Holocene. Obviously, in view of the very simple U diffusion model used here to estimate $\mathrm{z}_{\mathrm{U}}$, the calculated depths must be considered with caution. More realistic modeling of the $U$ data, however, requires a better understanding of $U$ diffusion into deep-sea sediments, especially in those with low organic carbon content but very high authigenic $U$ concentrations, such as found throughout most of this core. Moreover, a perfect agreement between $z_{U}$ and opal plus carbonate rain rates should not necessarily be expected. The ratio between the flux of planktonic organic matter and biogenic hard parts can vary with plankton ecology and the degree of opal and carbonate preservation on the seafloor. Also, because $z_{U}$ reflects the redox conditions of the sediment, it depends not only on vertical rain rates, but also on the nature of the sediment which is redistributed by bottom currents. Shallower $\mathrm{z}_{U}$ 's during late Holocene, when biogenic rain rates were relatively small, could thus be the result of higher labile organic matter content in the sediment redistributed during that period, or higher organic matter concentration in the 
settling biogenic flux. These possibilities appear substantiated by the comparatively high $\% \mathrm{~N}$ found in this core section (Figure 6).

Comparison Between Opal Accumulation Rates and Opal Rain Rates Reconstructed by ${ }^{230}$ Th Normalization

One of the initial goals of this study was to establish the extent to which sediment redistribution in this region could influence opal accumulation rates and bias opal productivity estimates reconstructed from such measurements. When comparing our ${ }^{230}$ Th-normalized opal rain rates to opal accumulation rates (estimated by multiplying opal concentrations by dry bulk densities and sediment accumulation rates of $27,2.5$, and $17 \mathrm{~cm} \mathrm{kyr}^{-1}$ for isotopic stage 1,2, and 3 respectively), we note dramatic differences between the two records (Figure 8). Opal accumulation is severalfold higher than our estimated rain rates during isotopic stage 1 and 3 and increases abruptly at the onset of deglaciation.

These differences mainly arise because sediment accumulation at this location is primarily controlled by syndepositional sediment redistribution processes or focusing. Suman and Bacon [1989] define a focusing factor $(\Psi)$ as the ratio of ${ }^{230}$ Th accumulating on the seafloor to ${ }^{230}$ Th produced in the overlying water column during the time interval of sediment deposition, i.e.,

$\Psi=\frac{\int_{r_{2}}^{r_{1}}\left[{ }^{230} T h\right]_{0} \rho_{b} d r}{\beta z\left(t_{1}-t_{2}\right)}$

where $[230 \mathrm{Th}]_{0}$ is the activity of the decay- and ingrowthcorrected excess ${ }^{230} \mathrm{Th}$ in the sediment, $\mathrm{r}$ is depth in the core, and $t$ is the age of horizon $r$. The values $\rho b, \beta$, and $z$ are as defined for equation (1).

Application of equation (7) to different sections of core MD84-527 (Table 6, Figure 9) indicates that the amount of ex. ${ }^{230} \mathrm{Th}_{\mathrm{O}}$ which accumulated at the coring location exceeded that which was produced in the overlying water column by a factor of 4 during isotopic stage 3 and by as much as a factor of 12 during the Holocene, confirming that a large fraction of the sediment reaching the coring site during these periods was brought by syndepositional redistribution processes. In

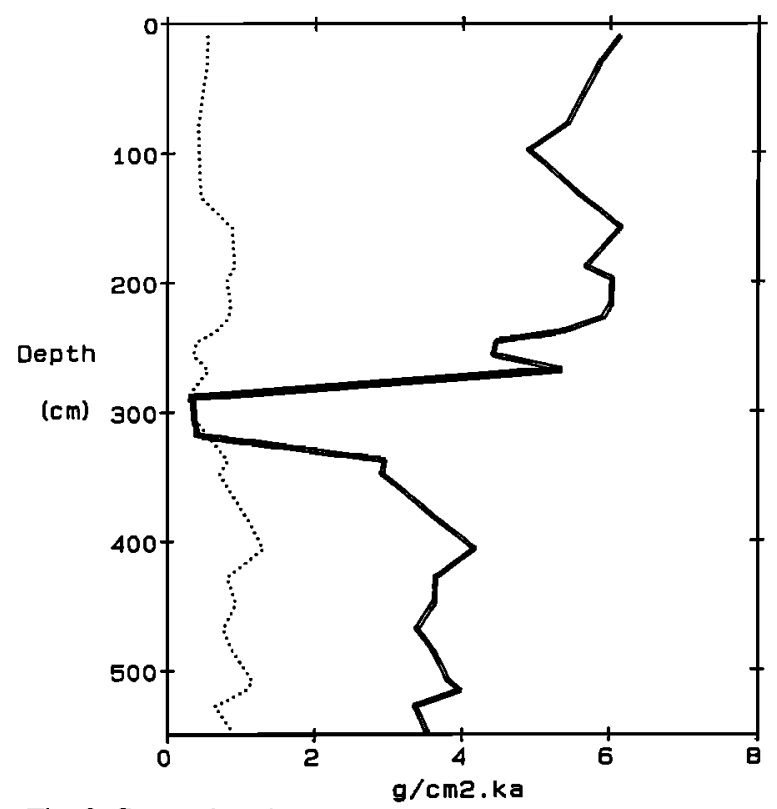

Fig. 8. Comparison between opal accumulation rates (double line; opal concentrations $\mathrm{x}$ dry bulk densities $\mathrm{x}$ sediment accumulation rates) and ${ }^{230} \mathrm{Th}$-normalized opal rain rates (dotted line).

contrast, $\Psi$ is close to 1 during isotopic stage 2 , strongly suggesting that sedimentation at that time was dominated by pelagic settling from the overlying water column, with little net addition by lateral transport or removal by winnowing. If the ${ }^{230} \mathrm{Th}$ concentration in the redistributed sediment is equal to that of the sediment raining down from the overlying water column (i.e., if the redeposited sediment came from an area of similar water depth, subjected to similar vertical rain rates), $\Psi$ is also the ratio of sediment accumulation rate (due to both vertical settling and lateral transport by bottom currents) to vertical settling rate only. On the other hand, it is also possible that the redistributed sediment was initially deposited in a shallower area before being transported to its final site of deposition. In this case, it can be shown that $\Psi$ would underestimate the fraction of sediment brought by lateral transport and ${ }^{230}$ Th-normalized paleofluxes would overestimate true rain rates [Francois et al., 1990].

TABLE 6. Calculation of Focusing Factor ( $\Psi$ )

\begin{tabular}{rcccccc}
\hline $\begin{array}{c}\text { Depth, } \\
\mathrm{cm}\end{array}$ & $\begin{array}{c}\text { Age, } \\
\mathrm{ka}\end{array}$ & $\begin{array}{c}\rho, \\
\mathrm{g} / \mathrm{cm}^{3}\end{array}$ & $\begin{array}{c}\text { 230Th } \\
\text { [230Th], } \\
\mathrm{dpm} / \mathrm{g}\end{array}$ & $\begin{array}{c}\text { 230Th } \\
\text { accumulation } \\
\text { rate, } \\
\text { dpm/cm } 2\end{array}$ & $\begin{array}{c}\text { production } \\
\text { rate, } \\
\text { dpm/cm } \mathbf{c m}^{2}\end{array}$ & $\Psi$ \\
\hline $0-146$ & $1.8-6.9$ & 0.39 & 9.7 & 552 & 44.3 & 12.5 \\
$146-233$ & $6.9-9.9$ & 0.39 & 5.6 & 190 & 25.8 & 7.36 \\
$242-291$ & $10.2-13.0$ & 0.42 & 8.7 & 179 & 24.1 & 7.43 \\
$291-321$ & $13.0-25.0$ & 0.36 & 8.3 & 90 & 103 & 0.87 \\
$321-558$ & $25.0-39.0$ & 0.36 & 5.5 & 469 & 120 & 3.9 \\
\hline
\end{tabular}



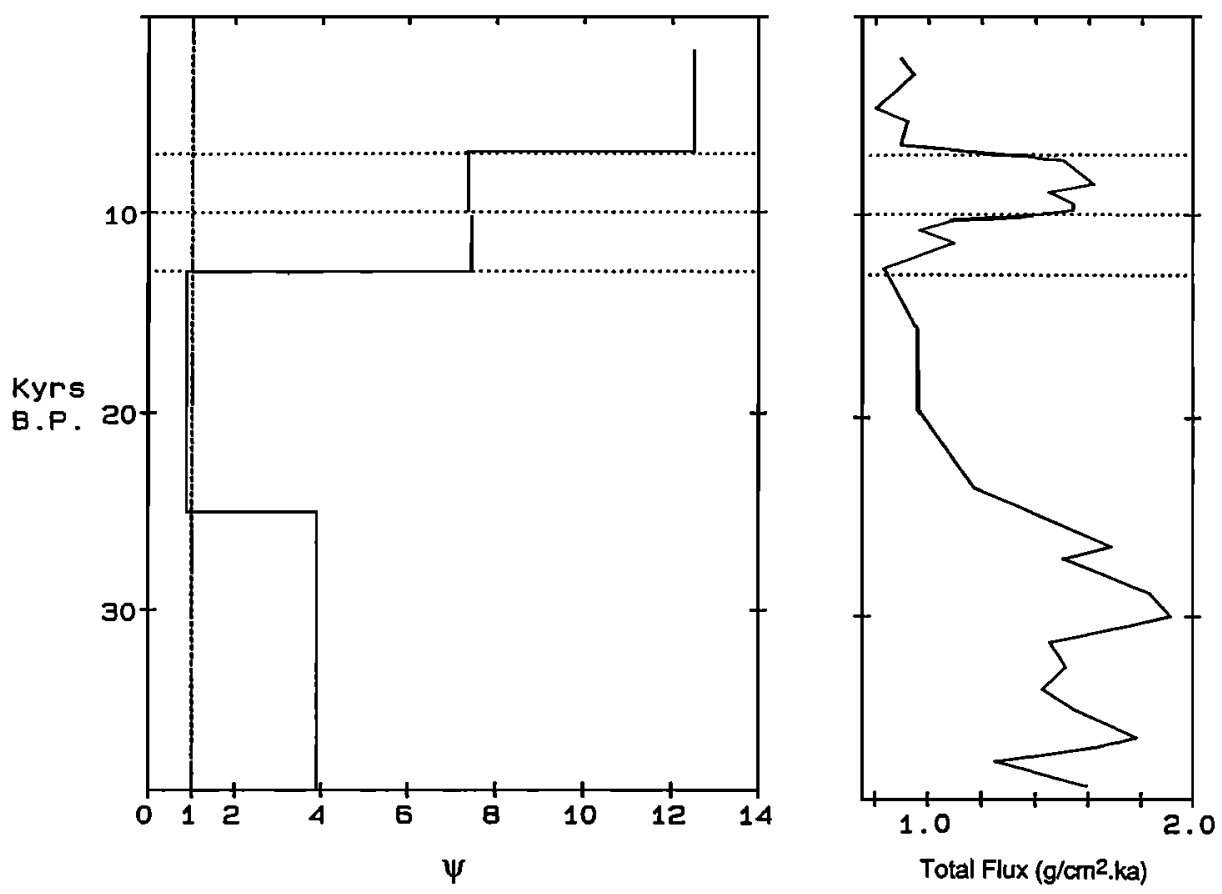

Fig. 9. Changes in focussing factor $(\Psi)$ in different core sections compared to changes in total ${ }^{230}$ Th-normalized fluxes.

Several lines of evidence suggest that this potential problem is not important for core MD84-527.

If lateral transport of sediment initially deposited in shallower areas significantly affected paleoflux estimates, we would expect a correlation between the two, i.e. the higher $\Psi$, the higher ${ }^{230} \mathrm{Th}$-normalized paleoflux. Also, we would expect to observe discontinuities in the paleoflux record at times when abrupt changes in sediment accumulation rate and sediment focussing occur (i.e., near 13 and 25 kyr B.P.). This is generally not observed. Although there is a relatively large drop in paleoflux near $25 \mathrm{kyr}$ B.P. (Figure 4), when sediment accumulation (Figure 2) and sediment focusing (Figure 9) decreased abruptly, there is no associated increase in paleoflux at the $13 \mathrm{kyr}$ horizon where sediment accumulation and focussing increase sharply. Instead, a rapid increase in paleoflux occurs at circa $10 \mathrm{kyr}$ B.P., i.e., $60 \mathrm{~cm}$ above the zone of abrupt change in accumulation rate, and is not associated with a measurable variation in $\Psi$. Also, during the last 7000 years, total paleoflux dropped by almost a factor of 2 (Figure 4) while $\Psi$ increased from 7.5 to 12.5 (Figure 9 , Table 6). This trend is opposite to expectation if lateral transport of sediment initially deposited in a shallower area were to influence paleoflux estimates.

Since lateral transport does not appear to affect significantly the paleoflux estimates, the redistributed sediment must come from an area of similar depth and vertical rain rates as the site of final deposition. The source of this sediment is probably the north slope of Crozet Plateau, just west of the coring location (Figure 1). Hydrographic data from the region [Gamberoni et al., 1982; Park et al., 1991] indicate that the northward deflection of the circumpolar current results in relatively strong eastward currents which could scour the northern slope of the Plateau. The dramatic changes in accumulation rates observed in this core (Figure 2) most likely reflect a reduction or a shift in the position of these currents during isotopic stage 2, associated with the climatically induced northward migration of the front system.

If we accept that $\Psi$ is also an estimate of the ratio of total sediment accumulation rate over pelagic rain rate, we can calculate the relative proportion of sediment brought by lateral transport and vertical settling. Between 0 and $7 \mathrm{kyr}$ B.P., 12.5 times (Table 6) more sediment accumulated at the coring station than can be accounted for by the pelagic rain rate of circa $0.9 \mathrm{~g} \mathrm{~cm}^{-2} \mathrm{kyr}^{-1}$ (Table 4). Thus, in this core section, sediment accumulation rate was $12 \times 0.9 \mathrm{~g} \mathrm{~cm}^{-2} \mathrm{kyr}^{-1}$ $=10.8 \mathrm{~g} \mathrm{~cm}^{-2} \mathrm{kyr}^{-1}$, and lateral transport rate was $(10.8-0.9)$

TABLE 7. Estimates of Vertical Rain Rates and Sediment Focusing Rates in MD84-527

\begin{tabular}{|c|c|c|c|}
\hline $\begin{array}{c}\text { Time, } \\
\text { ka }\end{array}$ & $\begin{array}{c}\text { Vertical } \\
\text { Rain Rate, } \\
\mathrm{g} / \mathrm{cm}^{-2} \mathbf{k a}^{-1}\end{array}$ & $\begin{array}{l}\text { Focusing } \\
\text { Rate, } \\
\mathrm{g} / \mathrm{cm}^{-2} \mathbf{k a}^{-1}\end{array}$ & $\begin{array}{c}\text { Total } \\
\text { Accumulation } \\
\text { Rate, } \\
\mathrm{g} / \mathrm{cm}^{-2} \mathrm{ka}^{-1}\end{array}$ \\
\hline $0-7$ & 0.9 & 10.2 & 11.1 \\
\hline $7-10$ & 1.5 & 9.8 & 11.3 \\
\hline $10-13$ & 1.0 & 6.4 & 7.4 \\
\hline $13-25$ & 1.0 & -0.1 & 0.9 \\
\hline $25-38$ & 1.6 & 4.6 & 6.2 \\
\hline
\end{tabular}


$\mathrm{g} \mathrm{cm}^{-2} \mathrm{kyr}^{-1}$. Results obtained using a similar reasoning for the other core sections are shown in Table 7.

This table clearly indicates that in areas where sediment accumulation is dominated by lateral transport, as in the present case, significant changes in vertical rain rate will not necessarily be expressed by measurable changes in accumulation rate. Thus, in this kind of environment, opal accumulation rates on the seafloor cannot be used alone as a proxy for opal production in the overlying water column, but Th-normalization enables us to retrieve information on rain rates which would otherwise be lost.

\section{Interpretation of the ${ }^{230}$ Th-Normalized Paleoflux Records}

Comparison between opal rain rates and accumulation rates has demonstrated the potential importance of ${ }^{230} \mathrm{Th}$ normalization for the reconstruction of changes in opal production rates in the southern ocean. Although a clear understanding of productivity changes in this region during the last glacial maximum (LGM) will require the analysis of many more cores, we here attempt a preliminary interpretation of the record obtained from MD84-527.

Micropaleontological reconstructions of surface circulation in the SW Indian Ocean during LGM suggest a northward migration in the position of the STC and PF [Hays et al., 1976; Prell et al., 1980; Pichon et al., 1992]. For instance, while the LGM section of core RC14-7 (35'31'S; $\left.44^{\circ} 45^{\prime} \mathrm{E}\right)$ was still dominated by a subtropical foraminiferal assemblage, that of core RC14-9 (39 $\left.01^{\prime} \mathrm{S} ; 4^{\circ} 53 \mathrm{E}\right)$ was dominated by subpolar assemblages, indicating that in this region the STC migrated north of $39^{\circ} \mathrm{S}$ from its present position at $41^{\circ}-42^{\circ} \mathrm{S}$ [Prell et al., 1980]. Also, the foraminiferal record of the LGM section of core RC8-39 $\left(42^{\circ} 53^{\prime} \mathrm{S} ; 42^{\circ} 21^{\prime} \mathrm{E}\right)$ revealed the presence of a polar assemblage, indicating that the Polar Front migrated north of $43^{\circ} \mathrm{S}$. The Polar Front appears to have migrated more than the STC, resulting in a contraction of the subantarctic zone during LGM.

The sediment from the LGM section of core MD84-527 was therefore deposited when the overlying surface water was situated south of the Polar Front. This is consistent with the low carbonate content in this core section (circa 12\%; Table 4), and estimates of sea surface temperature (SST) from foraminifera [Labracherie et al., 1989] and diatom [Labeyrie et al., 1986; Pichon et al., 1992] assemblages, indicating surface temperatures below $3^{\circ} \mathrm{C}$ (Figure 10). At $13 \mathrm{kyr}$ B.P., summer SST started to increase to circa $6^{\circ} \mathrm{C}$. This warming trend was interrupted by a brief cooling event between 11 and $12 \mathrm{kyr}$ B.P., after which summer surface temperatures increased to a maximum of circa $9^{\circ} \mathrm{C}$ between 8.5 and 10.2 $\mathrm{kyr}$, when surface temperatures were slightly higher than recorded during late Holocene.

Particle rain rates started to increase abruptly as SST was reaching its maximum value (Figure 10 ). Considering the steep temperature gradient at the STC, the early Holocene SST maximum could reflect the southernmost advance of this front in response to warming climatic conditions.

Temperature maxima during early interglacials appear to be a recurring feature over the last 450,000 years and have been interpreted as periods of maximum southward migration of

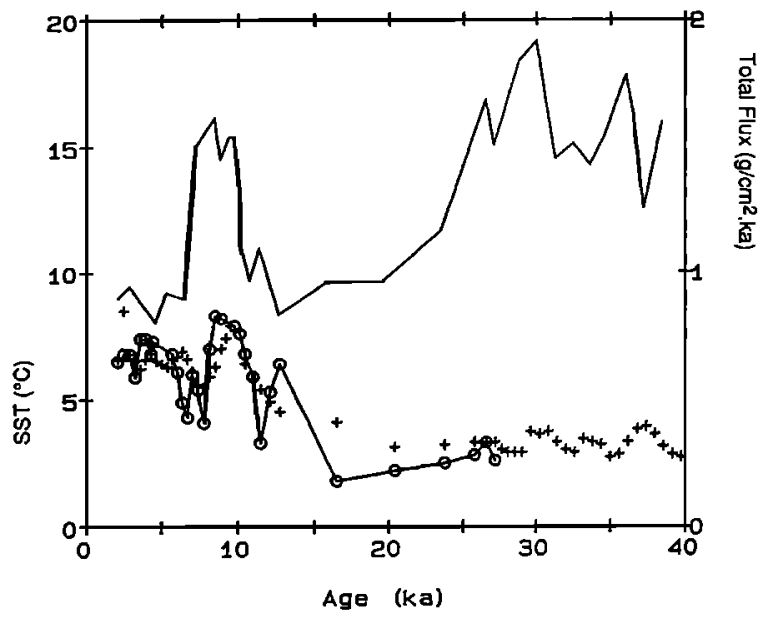

Fig. 10. Changes in total flux (solid line) and sea surface temperature evaluated from foraminifera (circles [Labracherie et al., 1989]) and diatom (crosses [Labeyrie et al., 1986; Pichon et al., 1992]) assemblages.

the STC [Morley, 1989; Howard and Prell, 1992]. In present day southern ocean, higher levels of chlorophyll and plankton biomass are often associated with the Subtropical

Convergence, in sharp contrast with subantarctic waters [e.g., Steyaert, 1973; Plancke, 1977; Jacques and Minas, 1981;

Allanson et al., 1981; Lutjeharms et al., 1985; Francois et al., 1993]. Primary production could be enhanced in this region as a result of increased water column stability from sloping isopycnals, or injection of nutrients into well-stratified subtropical waters and mixing by cross-frontal eddies [Pingree, 1978]. As a consequence, the STC must be a region of enhanced flux to the seafloor in comparison to neighboring regions to the south. The early Holocene maximum in paleoflux and ex. ${ }^{231} \mathrm{~Pa} / \mathrm{ex}^{230} \mathrm{Th}_{\mathrm{O}}$ activity ratio found in MD84-527 could thus record higher particle settling flux resulting from the proximity of the STC to the north of the coring site when the front was at its southernmost position. Alternatively, it could also record a general increase in the productivity of subantarctic waters. Analysis of cores taken along a latitudinal transect crossing the STC and the Polar Front is required to distinguish between these two possibilities.

The higher particle flux found during that period was mainly due to higher opal flux, which increased abruptly at $10 \mathrm{kyr}$ B.P.(Figure 4). There was also a higher carbonate flux which appeared to increase slightly prior to the opal flux, at $10.3 \mathrm{kyr}$ B.P., in synchroneity with the SST record. At circa $8 \mathrm{kyr}$ B.P., SST started to decrease, followed by opal and carbonate fluxes at circa $7.5 \mathrm{kyr}$ B.P., possibly reflecting a small northward migration of the STC to its present position.

Sediment $\delta^{15} \mathrm{~N}$ also shows a striking pattem in relation to the paleoflux record. During stage 2 and deglaciation, sediment $\delta^{15} \mathrm{~N}$ was comparatively high. Just prior to $10 \mathrm{kyr}$ B.P., i.e. exactly at the time when opal and carbonate paleofluxes increased sharply, sediment $\delta^{15} \mathrm{~N}$ dropped from 6.2 to 4.5 per mil (Table 4, Figure 11). Higher sediment $\delta^{15} \mathrm{~N}$ has been taken as an indication of increased nitrate depletion 

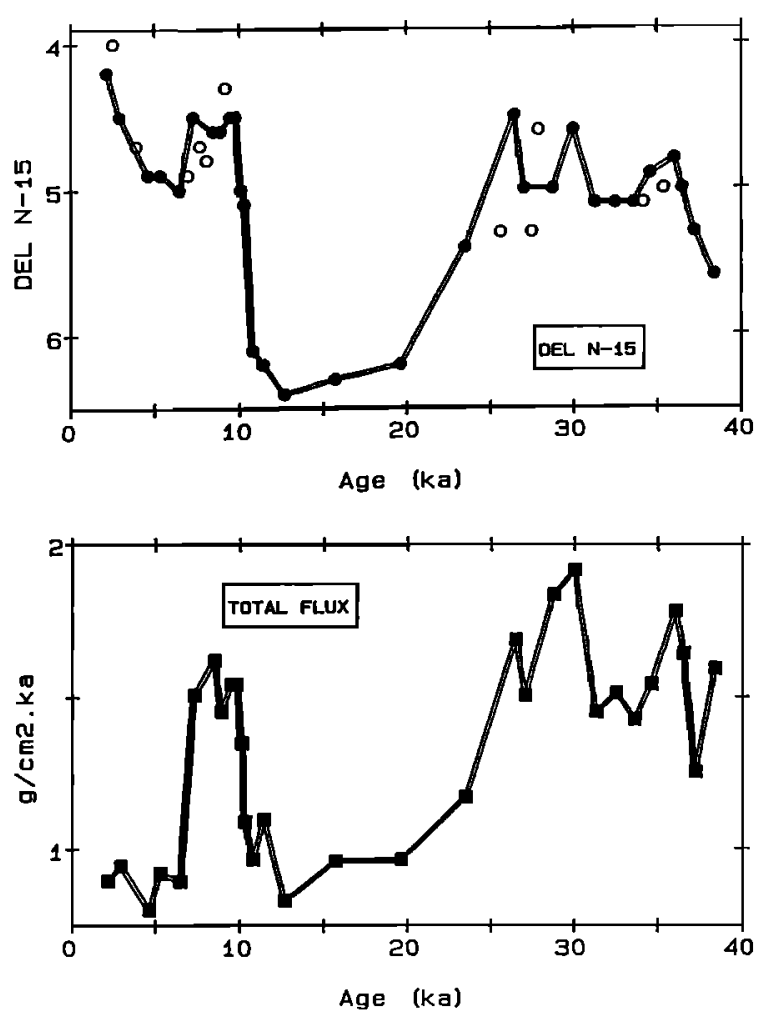

Fig. 11. Comparison between changes in sediment $\delta^{15} \mathrm{~N}$ (per $\mathrm{mil}$ ) and total ${ }^{230} \mathrm{Th}$-normalized paleoflux $\left(\mathrm{g} / \mathrm{cm}^{-2} \mathrm{ka}^{-1}\right)$. Open circles are additional $\delta^{15} \mathrm{~N}$ values without corresponding ${ }^{230} \mathrm{Th}$ measurements.

in the overlying surface waters [Calvert et al., 1992; Francois et al., 1992; Altabet and Francois, submitted manuscript, 1993]. Increased nitrate utilization across the STC from subpolar to subtropical water is reflected by an abrupt increase in the $\delta^{15} \mathrm{~N}$ of suspended particulate organic matter [Altabet and Francois, submitted manuscript, 1993]. One would thus expect that, as the STC reaches its southernmost position (i.e., between 8 and $10 \mathrm{kyr}$ ), so would sediment $\delta^{15} \mathrm{~N}$ reach its maximum value. However, the reverse is observed, i.e., as we reach the point of maximum southward advance of the STC and maximum flux of biogenic material, sediment $\delta^{15} \mathrm{~N}$ decreases. This suggests that paleofluxes do not simply reflect the latitudinal migration of the frontal system, but in addition there must have been significant changes in the structure of the upper water column. Higher $\delta^{15} \mathrm{~N}$ suggests higher nitrate depletion during the last glacial maximum when the coring site was south of the polar front, and during deglaciation, prior to $10 \mathrm{kyr}$. Yet these periods are characterized by low biogenic fluxes and thus must have been periods of low biological productivity. If our interpretations of radionuclides and $\delta^{15} \mathrm{~N}$ sediment profiles are correct, they imply a dramatic reduction in the rate of nutrient supply to the euphotic zone.

One mechanism whereby this could be achieved is through stratification of the upper water column with a meltwater lid.
Anomalies in the $\delta^{18} \mathrm{O}$ of planktonic foraminifera, estimated by subtracting the benthic signal from the planktonic and correcting for estimated changes in temperature in both surface and deep waters, suggest the presence of low salinity surface water during stage 2 and deglaciation [Labeyrie et al., 1986]. This is also consistent with the presence of percent $C$. davisiana which drops abruptly at the onset of high ${ }^{230} \mathrm{Th}$ normalized rain rate (Figure 12). It has been suggested that the predominance of $C$. davisiana in many glacial sediments of the southern ocean is a result of low surface salinity and a subsurface temperature minimum similar to that prevailing today in the sea of Okhotsk [Morley and Hays, 1983].

The freshwater supply from melting of the Antarctic Ice Sheet must have stopped at the end of deglaciation, at a time when climatic conditions were such that the STC was at its southernmost position and close to the coring site. The upper water column became well mixed, increasing the rate of supply of nutrients and lowering $\delta^{15} \mathrm{~N}$ to values which are more typical of present day polar rather than subpolar waters [Altabet and Francois, submitted manuscript, 1993; Francois et al., 1992]. This might be difficult to reconcile with the explanation that increased paleoflux is a reflection of the proximity of the STC, although SST estimates support this idea. This apparent discrepancy may be due to the particular hydrographic setting of this region, where the northward deflection of the ACC causes the SAF and STC to merge, almost eliminating the subpolar zone [Gamberoni et al., 1982; Park et al., 1991].

The abrupt decrease in flux recorded at circa 7.5 kyr B.P. was not associated with significant variations in $\delta^{15} \mathrm{~N}$. The change in opal and carbonate productivity found at that time was not associated with changes in nitrate utilization, which remained low and equivalent to that observed for the most recent sediment samples. The SST record suggests that this drop in productivity may have been due to a slight northward shift in the position of the STC. The decreasing $\delta^{15} \mathrm{~N}$ trend

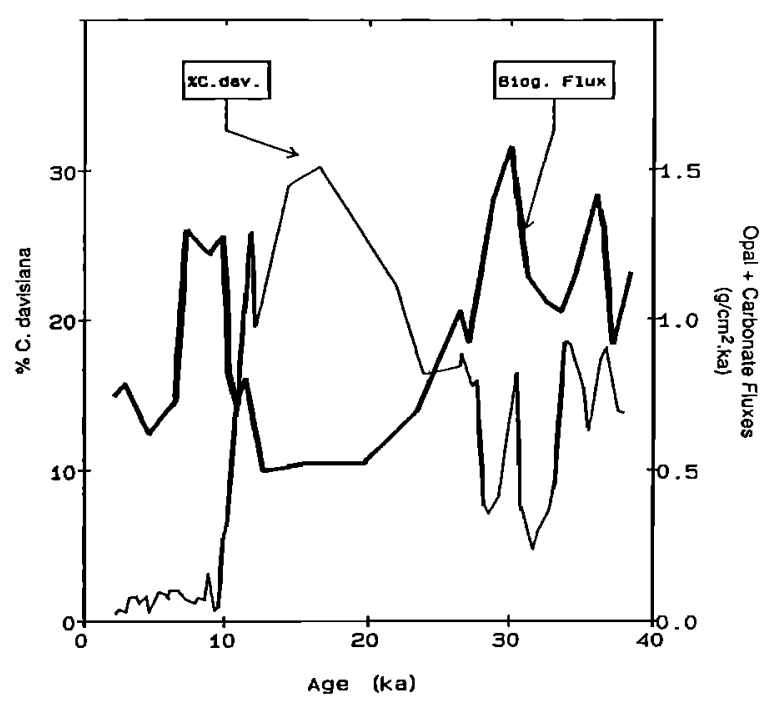

Fig. 12. Comparison between percent $C$. davisiana (relative abundances [Bareille, 1991]) and ${ }^{230}$ Th-normalized biogenic (carbonate + opal) paleoflux. 
observed during the last $\mathbf{5 0 0 0}$ years is compatible with this explanation.

With the available data, it is difficult to evaluate the causes of the changes in paleofluxes recorded during isotopic stage 3 . During this period, changes in flux are not associated with significant changes in SST (Figure 10). Diatom assemblages suggest very low and relatively constant surface temperature similar to polar waters, precluding shifts in the position of the STC as causes for the higher fluxes centered at 30 and $36 \mathrm{kyr}$. Sediment $\delta^{15} \mathrm{~N}$ was significantly lower during stage 3 compared to the LGM and equivalent to Holocene values (Figure 10), suggesting a well-mixed upper water column throughout this period. The Polar Front is also often associated with chlorophyll maxima [e.g., Allanson et al., 1981; Lutjeharms et al., 1985; Metzl et al., 1991]. During stage 3, the Polar Front might have been situated near the core location. The variable paleofluxes recorded during that period could thus reflect small latitudinal shifts in the position of this front.

\section{CONCLUSIONS}

High-resolution records of opal, carbonate, and terrigenous fluxes to the seafloor were obtained by normalization to ${ }^{230} \mathrm{Th}$ in a high sedimentation rate core taken from the subantarctic region of the SW Indian Ocean. We demonstrated that the dramatic changes in accumulation rates recorded in this core were due to changes in lateral transport by bottom currents rather than reflecting changes in particle settling rates from the overlying water column. In this case, opal accumulation rates cannot be used to assess past changes in diatom productivity. This information can be obtained, however, by normalization to ${ }^{230} \mathrm{Th}$ which corrects for syndepositional sediment redistribution. Also, the improved time resolution achieved by this method discloses important variations in rain rates. We found relatively high but variable opal and terrigenous fluxes during isotopic stage 3, low opal and high terrigenous fluxes during LGM, low opal with decreasing terrigenous fluxes during deglaciation, low terrigenous fluxes throughout the Holocene, and a pronounced maximum in opal and carbonate fluxes, associated with a SST maximum, between 7.5 and $10 \mathrm{kyr}$ B.P. Sediment deposited during periods of high opal fluxes also had high authigenic $U$ concentrations, suggesting more reducing conditions in the sediment, and high ex. ${ }^{231} \mathrm{~Pa} / \mathrm{ex} .{ }^{230} \mathrm{Th}$ ratios, indicating enhanced scavenging of reactive metals from the water column by settling particles.

Sediment $\delta^{15} \mathrm{~N}$ was circa 1.5 per mil higher during LGM and deglaciation. The low opal rain rates recorded during these periods thus appear to have been associated with increased nitrate utilization, suggesting lower nutrient supply rates into surface waters, possibly reflecting water column stratification due to the presence of a meltwater lid. The early Holocene opal and carbonate flux maximum has been attributed to the southward migration of the STC to a latitude close to the north of the coring site, while the opal maxima recorded during isotopic stage 3 are thought to reflect the proximity of the Polar Front. A more definitive interpretation of these profiles will require additional data from cores taken along a latitudinal transect in this region.
This work demonstrates the potential of ${ }^{230}$ Th normalization as a means of retrieving flux information relevant to upper water column processes in regions where sediment accumulation is dominated by bottom current redistribution. It also illustrates the potential errors which can result from interpreting changes in opal accumulation rates in sediments as variations in opal production. Application of this approach to a large numbers of cores from the southern ocean will provide a more accurate reconstruction of the past history of opal productivity in this region, add insight into changes in bottom water circulation and sites of sediment focusing and improve our global silica budget estimates.

Acknowledgements. We thank P. Froelich, Y. Lao, and an anonymous reviewer for constructive reviews, A. P. Fleer for assistance with radiochemical analysis, and J. Donahue for assistance with nitrogen isotope measurements. This work was suported by NSF grants OCE-8922707 and DPP-9118031 and also benefitted from the use of the MIT research reactor with support from U.S. DOE Reactor Sharing Grant DEFG07-80ER10770.A015. Core MD 84-527 was obtained during cruise APSARA of R. V. Marion-Dufresne (J. L. Turon and M. Fontugne Chief Scientists) with the support of Mission Scientifique des Terres Australes et Antarctiques Francaises for the French "Programme National de la Dynamique du Climat". This program is supported by Institut National des Sciences de l'Univers. L. Labeyrie's research is also supported by Centre National de la Recherche Scientifique and Commissariat a l'Energie Atomique. The role of $\mathbf{M}$. Labracherie (DGO Universite Bordeaux 1) for the coordination with L. Labeyrie of the Southern Ocean research must be specially acknowledged. This is WHOI contribution 8201.

\section{REFERENCES}

Allanson, B. R., R. C. Hart, and J. R. E. Lutjeharms, Observations on the nutrients, chlorophyll and primary production of the southern ocean south of Africa, S. Afr. $J$. Antarct. Res., 10/11, 3-14, 1981.

Altabet, M. A., W. G. Deuser, S. Honjo, and C. Stienen, Seasonal and depth-related changes in the source of sinking particles in the north Atlantic detected by ${ }^{15} \mathrm{~N} /{ }^{14} \mathrm{~N}$ ratios, Nature, 354, 136-139, 1991.

Anderson, J. B., Sediments, in Antarctic Sector of the Pacific, Oceangr. Ser., vol. 51, edited by G. P. Glasby, pp. 187-205, Elsevier, New York, 1990.

Anderson, R. F., Concentration, vertical flux, and remineralization of particulate uranium in seawater, Geochim. Cosmochim. Acta, 46, 1293-1299, 1982.

Anderson, R. F., and A. P. Fleer. Determination of natural actinides and plutonium in marine particulate material, Anal. Chem., 54, 1142-1147, 1982.

Anderson, R. F., M. P. Bacon, and P. G. Brewer, Removal of Th-230 and Pa-231 at ocean margins, Earth Planet. Sci. Lett., 66, 73-90, 1983.

Anderson, R. F., A. P. LeHuray, M. Q. Fleisher, and J. W. Murray, Uranium deposition in Saanich Inlet sediments, Vancouver Island, Geochim. Cosmochim. Acta, 53, 22052213, 1989.

Anderson, R. F., Y. Lao, W. S. Broecker, S. E. Trumbore, H. 
J. Hofmann, and W. Wolfli, Boundary scavenging in the Pacific Ocean: A comparison of Be-10 and Pa-231, Earth Planet. Sci. Lett., 96, 287-304, 1990.

Bacon, M. P., Glacial to interglacial changes in carbonate and clay sedimentation in the Atlantic ocean estimated from Th230 measurments, Isot. Geosci., 2, 97-111, 1984.

Bacon, M. P., Tracers of chemical scavenging in the ocean: Boundary effects and large scale chemical fractionation, Philos. Trans. R. Soc. London, Ser. A, 320, 187-200, 1988.

Bard, E., L. D. Labeyrie, M. Arnold, M. Labracherie, J.-J. Pichon, J. Duprat, and J.-C. Duplessy, AMS C-14 ages measured in deep-sea cores from the southern ocean: Implications for sedimentation rates during isotope stage 2, Quat. Res., 31, 309-317, 1989.

Barnes, C. E., and J. K. Cochran, Uranium removal in oceanic sediments and the oceanic U balance, Earth Planet. Sci. Lett., 97, 94-101, 1990.

Bareille, G., Flux sédimentaire: Paléoproductivité et paléocirculation de l'océan australe au cours des 150,000 dernières années, Ph.D. thesis, 259 pp., Univ. de Bordeaux I, TaPence, 1991.

Bareille, G., M. Labracherie, L. Labeyrie, J.-J. Pichon, and J.L. Turon, Biogenic silica accumulation rate during the Holocene in the southeastern Indian Ocean, Mar. Chem., 35, 537-551, 1991.

Calvert, S. E., B. Nielsen, and M. R. Fontugne, Evidence from nitrogen isotope ratios for enhanced productivity during formation of eastern mediterranean sapropels, Nature, 359, 223-225, 1992.

Charles, C. D., P. N. Froelich, M. A. Zibello, R. A. Mortlock, and J. J. Morley, Biogenic opal in southern ocean sediments over the last 450,000 years: Implications from surface water chemistry and circulation, Paleoceanography, 6, 697-728, 1991.

Cochran, J. K., and S. Krishnaswami, Radium, thorium, uranium and $\mathrm{Pb}-210$ in deep-sea sediments and sediment pore waters from the North Equatorial Pacific, Am. J. Sci., 280, 849-889, 1980.

Colley, S., J. Thomson, and J. Toole, Uranium relocations and derivation of quasi-isochrons for a turbidite/pelagic sequence in the Northeast Atlantic, Geochim. Cosmochim. Acta, 53, 1223-1234, 1989.

Fleer, A. P., and M. P. Bacon, Notes on some techniques of marine particle analysis used at WHOI, in Marine Particles: Analysis and Characterization, Geophys. Monogr. Ser., vol. 63, edited by D. C. Hurd and D. W. Spencer, pp. 223-226, AGU, Washington, D. C., 1991.

Francois, R., and M. P. Bacon, Variations in terrigenous input into the deep equatorial Atlantic during the past 24,000 years, Science, 251, 1473-1476, 1991.

Francois, R., M. P. Bacon, and D. O. Suman, Thorium-230 profiling in deep-sea sediments: High-resolution records of flux and dissolution of carbonate in the equatorial Atlantic during the last 24,000 years, Paleoceanography, 5, 761787, 1990.

Francois, R., M. A. Altabet, and L. D. Burckle, Glacial to interglacial changes in surface nitrate utilization in the Indian sector of the southern ocean as recorded by sediment $\delta^{15} \mathrm{~N}$, Paleoceanography, 7, 589-606, 1992.

Francois, R., M. A. Altabet, R. Goericke, D. C. McCorkle, C.
Brunet, and A. Poisson, Changes in the $\delta^{15} \mathrm{C}$ of surface water particulate organic matter across the Subtropical Convergence in the SW Indian Ocean, Global

Biogeochemical Cycles, 1993, in press.

Froelich, P. N., et al., Biogenic opal and carbonate accumulation rates in the subantarctic South Atlantic: The Late Neogene of Meteor Rise Site 704, Proc. Ocean Drill. Program Sci. Results, 114, edited by P. F. Ciesielski, 515550, 1991.

Gamberoni, L., J. Geronimi, P. F. Jeannin, and J. F. Murail, Study of frontal zone in the Crozet-Kerguelen region, Oceanol. Acta, 5, 289-299, 1982.

Hays, J. D., J. A. Lozano, N. J. Shackleton, and G. Irving, Reconstruction of the Atlantic and western Indian Ocean sectors of the 18,000 B.P. Antarctic Ocean, in Investigation of Late Quaternary Paleoceanography and Paleoclimatology, edited by R. M. Clines and J. D. Hays, Mem. Geol. Soc. Am., 145, 337-372, 1976.

Howard, W. R., and W. L. Prell, Late Quaternary surface circulation of the southern ocean and its relationship to orbital variations, Paleoceanography, 7, 79-117, 1992.

Heezen, B. C., and C. D. Hollister, The Face of the Deep, 657 pp., Oxford University Press, New York, 1971.

Hillaire-Marcel, C., A. Aksu, C. Causse, A. de Vernal, and B. Ghaleb, Response of Th/U in deep Labrador Sea sediments (ODP site 646) to changes in sedimentation rates and paleoproductivity, Geology, 18, 162-165, 1990.

Jacques, G., and M. Minas, Production primaire dans le secteur indien de l'ocean Antarctique en fin d'été, Oceanol. Acta, 4, 33-41, 1981.

Jones, G. A., and P. Kaiteris, A vacuum-gasometric technique for rapid and precise analysis of calcium carbonate in sediments and soils, J. Sed. Petrol., 53, 655-660, 1983.

Klinkhammer, G., and M. R. Palmer, Uranium in the oceans: Where it goes and why, Geochim. Cosmochim. Acta, 55, 1799-1806, 1991.

Knox, F., and M. B. McElroy, Changes in atmospheric $\mathrm{CO}_{2}$ : Influence of the marine biota at high latitude, J. Geophys. Res., 89, 4629-4637, 1984.

Labeyrie, L. D., J.-J. Pichon, M. Labracherie, P. Ippolito, J. Duprat, and J.-C. Duplessy, Melting history of Antarctica during the last 60,000 years, Nature, 322, 701-706, 1986.

Labracherie, M., L. D. Labeyrie, J. Duprat, E. Bard, M. Arnold, J.-J. Pichon, and J.-C. Duplessy, The last deglaciation in the southern ocean, Paleoceanography, 4, 629-638, 1989.

Lao, Y., R. F. Anderson, W. S. Broecker, H. J. Hofmann and W. Wolfli, Particulate fluxes of ${ }^{230} \mathrm{Th},{ }^{231} \mathrm{~Pa}$, and ${ }^{10} \mathrm{Be}$ in the northeastern Pacific Ocean, Geochim. Cosmochim. Acta, 57, 205-217, 1993.

Lutjeharms, J. R. E., N. M. Walters, and B. R. Allanson, Oceanic frontal systems and biological enhancement, in Antarctic Nutrient Cycles and Food Webs, edited by W. R. Siegfried, P. R. Condy, and R. M. Laws, pp. 11-21, Springer-Verlag, New York, 1985.

Metzl, N., C. Beauverger, C. Brunet, C. Goyet, and A. Poisson, Surface water carbon dioxide in the southwest Indian sector of the southern ocean: A highly variable $\mathrm{CO}_{2}$ source/sink region in summer, Mar. Chem., 35, 85-95, 1991. 
Minagawa, M, D. A. Hunter, and I. R. Kaplan, Comparison of Kjeldahl and combustion methods for measurement of nitrogen isotope ratios in organic matter, Anal. Chem., 56, 1859-1861, 1985.

Montoya, J. P., Natural abundance of ${ }^{15} \mathrm{~N}$ in marine and estuarine plankton: Studies of biological isotopic fractionation and plankton processes, Ph.D. thesis, Harvard Univ., Cambridge, Mass., 1990.

Morley, J. J., Variations in high-latitude oceanographic fronts in the southern Indian Ocean: An estimation based on faunal changes, Paleoceanography, 4, 547-554, 1989.

Morley, J. J., and J. D. Hays, Oceanographic conditions associated with high abundances of Radiolarian Cyclodophora davisiana, Earth Planet. Sci. Lett., 66, 63-72, 1983.

Mortlock, R. A., and P. N. Froelich, A simple method for the rapid determination of biogenic opal in pelagic marine sediments, Deep Sea Res., 36, 1415-1426, 1989.

Mortlock, R. A., C. D. Charles, P. N. Froelich, M. A. Zibello, J. Saltzman, J. D. Hays, and L. H. Burckle, Evidence for lower productivity in the Antarctic Ocean during the last glaciation, Nature, 351, 220-223, 1991.

Nakatsuka, T., N. Handa, E. Wada, and C. S. Wong, The dynamic changes of stable isotoic ratios of carbon and nitrogen in suspended and sedimented particulate organic matter during a phytoplankton bloom, J. Mar. Res., 50 , 267-296, 1992.

Park, Y.-H., L. Gamberoni, and E. Charriaud, Frontal Structure and Transport of the Antarctic Circumpolar Current in the South Indian Ocean Sector, $40-80^{\circ} \mathrm{E}, \mathrm{Mar}$. Chem., 35, 45-62, 1991.

Petit, J. R., L. Mounier, J. Jouzel, Y. S. Korotkevich, V. I. Kotlyakov, and C. Lorius, Paleoclimatological and chronological implications of the Vostok core dust record, Nature, 343, 56-58, 1990.

Pichon, J.-J., L. D. Labeyrie, G. Bareille, M. Labracherie, J. Duprat, and J. Jouzel, Surface water temperature changes in the high latitude of the southern hemisphere over the last glacial-interglacial cycle, Paleoceanography, 7, 289-318, 1992.

Pingree, R. D., Cyclonic eddies and cross-frontal mixing, $J$. Mar. Biol. Assoc. U.K., 58, 955-963, 1978.

Plancke, J., Phytoplankton biomass and productivity in the subtropical convergence area and shelves of the westem
Indian subantactic islands, in Adaptations within Antarctic Ecosystems, Proceedings of the third SCAR Symposium on Antarctic biology, 51-73, 1977.

Prell, W. L., W. H. Hutson, D. F. Williams, A. W. H. Bé, K. Geitzenauer, and B. Molfino, Surface circulation of the Indian Ocean during the last glacial maximum, approximately 18,000 yr B. P., Quat. Res., 14, 309-336, 1980.

Sarmiento, J. L., and R. Toggweiller, A new model for the role of the oceans in determining atmospheric $\mathrm{PCO}_{2}$, Nature, 308, 621-624, 1984.

Siegenthaler, U., and T. Wenk, Rapid atmospheric $\mathrm{CO}_{2}$ variations and ocean circulation, Nature, 308, 624-626, 1984.

Steyaert, J., Distribution of plankton diatoms along an African-Antarctic transect, Invest. Pesq., 37, 295-328, 1973.

Suman, D. O., and M. P. Bacon, Variations in Holocene sedimentation in the North American Basin determined by Th-230 measurements, Deep Sea Res., 36, 869-878, 1989.

Wada, E., and A. Hattori, Nitrkokgen isotope effects in the assimilation of inorganic nitrogenous compounds by marine diatoms, Geomicrobiol. J., 1, 85-101, 1978.

Watkins, N. D., and J. P. Kennett, Regional sedimentary disconformities and upper Cenozoic changes in bottom water velocities between Australiasia and Antarctica, in Antarctic Oceanology II: The Australian-New Zealand Sector, Antarctic Res. Ser., vol. 19, edited by D. E. Hayes, pp. 273-294, AGU, Washington, D. C., 1972.

Yang, H.-S., Y. Nozaki, H. Sakai, and A. Masuda, The distribution of Th-230 and $\mathrm{Pa}-231$ in the deep-sea surface sediments of the Pacific Ocean, Geochim. Cosmochim. Acta, 50, 81-89, 1986.

M. A. Altabet, M. P. Bacon, and R. Francois, Department of Marine Chemistry and Geochemistry, Woods Hole Oceanographic Institution, Woods Hole, MA 02543.

L. D. Labeyrie, Centre des Faibles Radioactivités, Laboratoire Mixte, Centre National de la Recherche Scientifique et Commissariat à l'Énergie Atomique, Gif-surYvette, France.

(Received November 18, 1992;

revised March 8, 1993;

accepted March 23, 1993.) 